\title{
السير البيليوجرافية
}

\section{عبد الله التديم \\ سيرة حياة|لصحافى، الخطيب، المصلح الاجتماعى، رؤيته لإصلاح التعليم ( $1 \wedge 99-1 \wedge \varepsilon r / M \mid r-1 Y q 1)$}

\author{
د. سيدة حامد عبد العال \\ أستاذ متفرغ بقسم اللغة العربية و آدابها \\ كلية الآداب - جامعة حلو ان لفئم
}

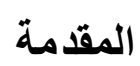

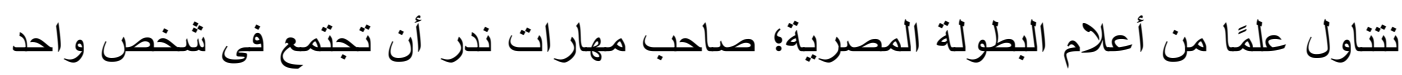

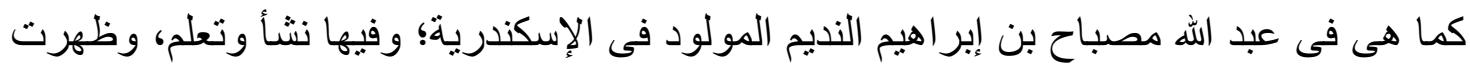

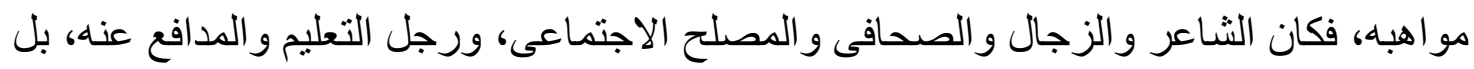

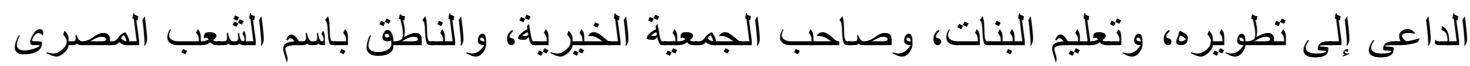

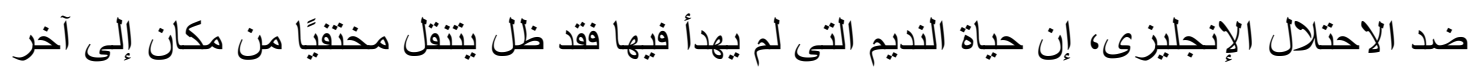

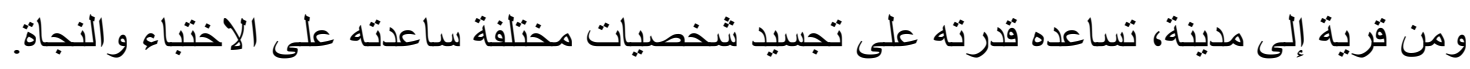

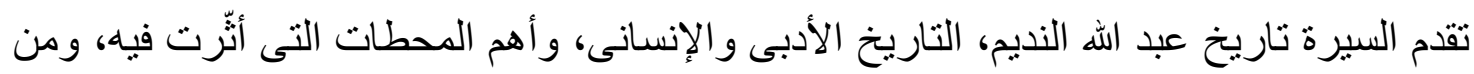

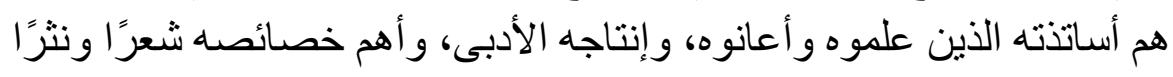

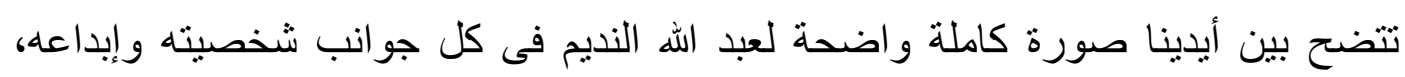

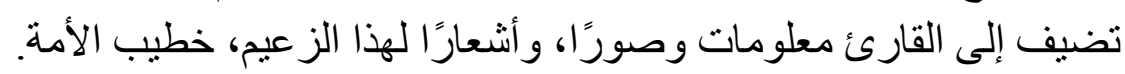
وكذلك لمن كتبوا عن النديم وإننى أثنكر د. مها مظلوم خضر على على دعمها لهذا البحث، ومساعدتها فى البيليو جر افيا الخاصة بالنديم والنيم. أولا : المولا والتنشئـة : عبد الله بن مصباح بن إبراهيم الإدريسي الحسيني؛ و إدريس من أسباط الحسن بن على بن 


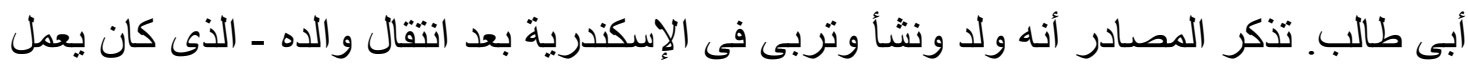

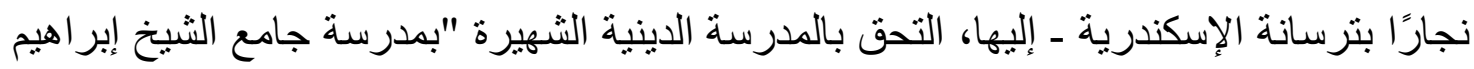

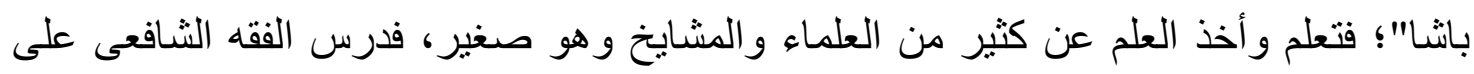

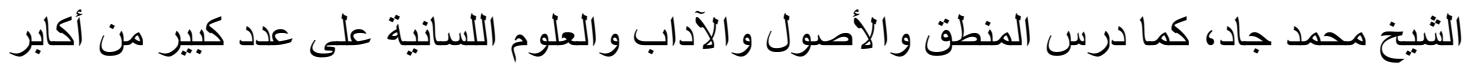
العلماء منهم الثيخ محمد العشرى، و الثيخ إبر اهيم السرسي، ولادئ والثيخ خفاجة.

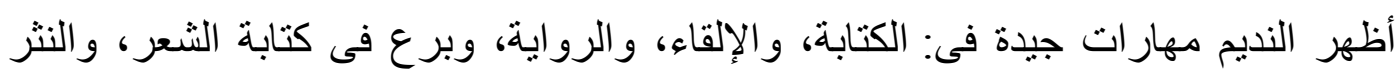
المسجوع؛ الذى تطور و أصبح فن "الزجل".

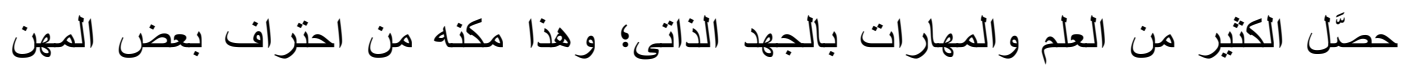

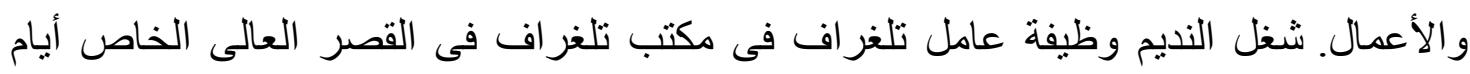

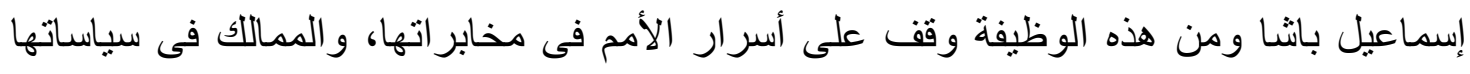

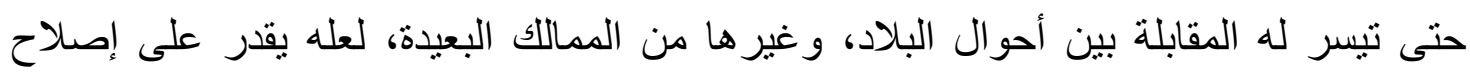

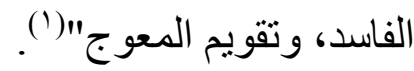

وفى وقت فر اغه كان يقرأ ويتعلم فى حلقات العلم بالأزهر عند انتقاله إلى القاهرة.

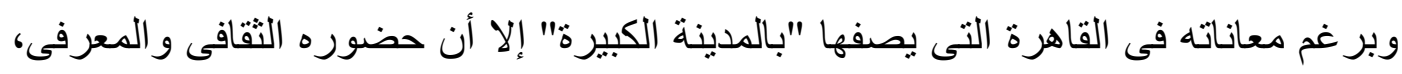

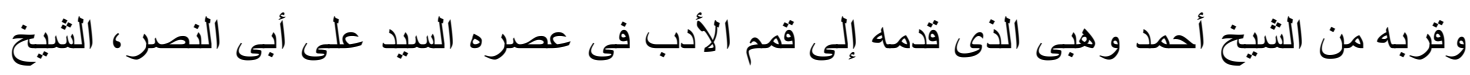

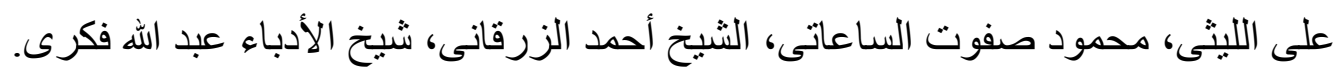

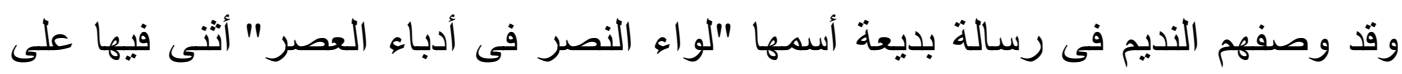
هؤلاء الأدباء و أدبهر.

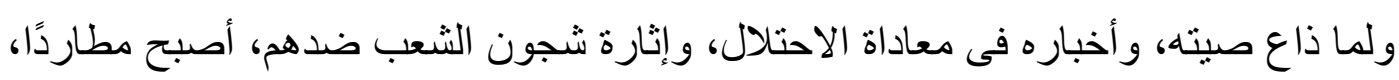

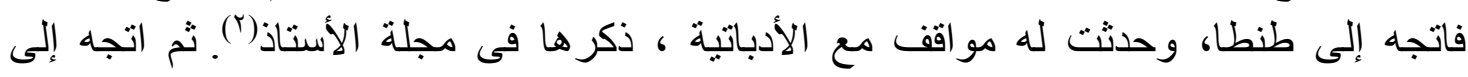

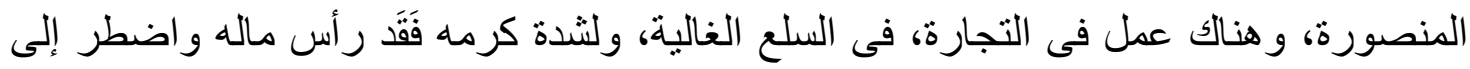
العودة إلى الإسكندرية.

وفى عام NV9 ( م ـ و أثناء وجوده فى الإسكندرية ـ فكر فى أن ينشئ ويقيم عملا خيريًا، لخدمة المو اطنين الفقر اء وتعليمهر. 


\section{الجمعية الخيرية الإسلامية :}

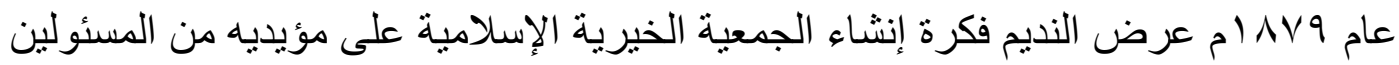

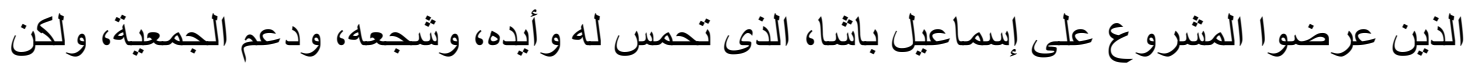

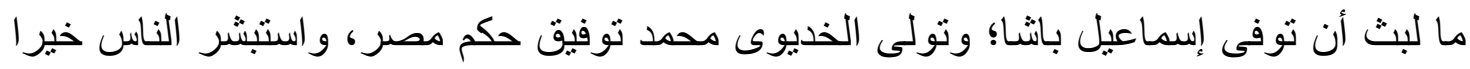

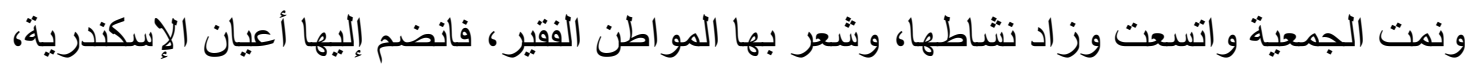
وفتحت الجمعية مدرسة لتعليم الفقر اءو واليتامى مجانًا.

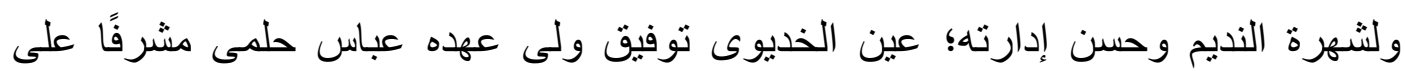

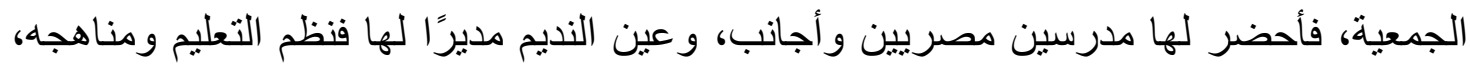

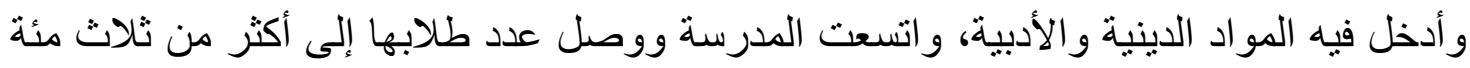

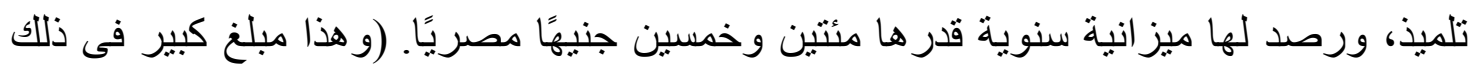

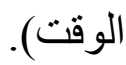

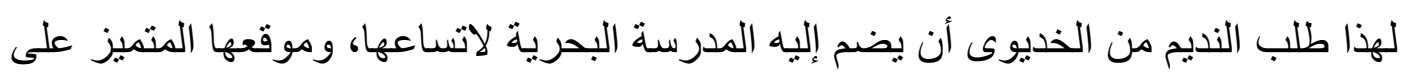

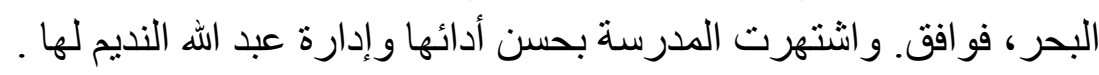

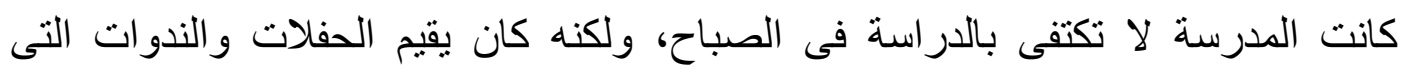

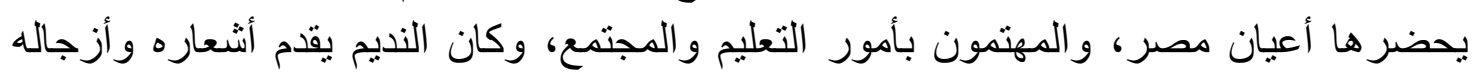

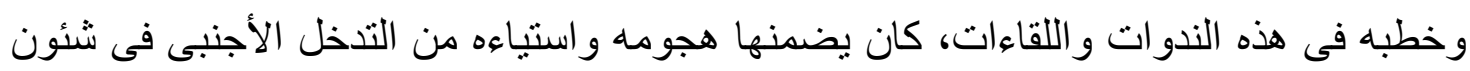

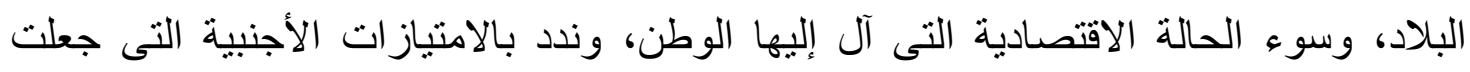

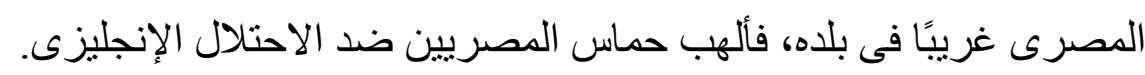

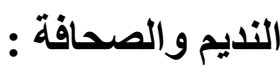

كان النديم يكتب كتابة أدبية فى جريدنى "المحروسة" و " العصر الجديد" رئيس التحرير سليم

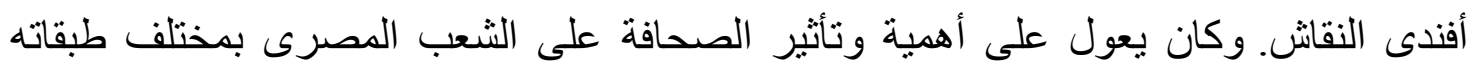

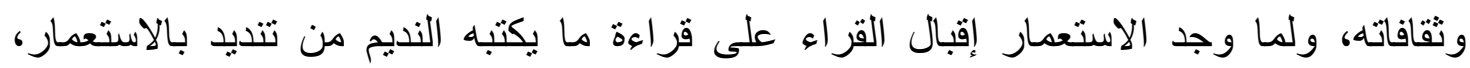

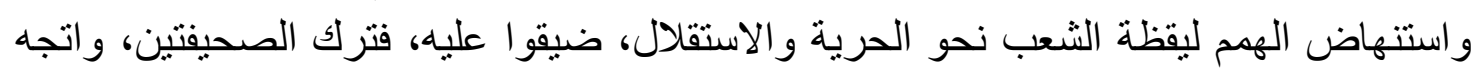
الى إنشاء الصحف النى رأس تحرير ها و هیى:

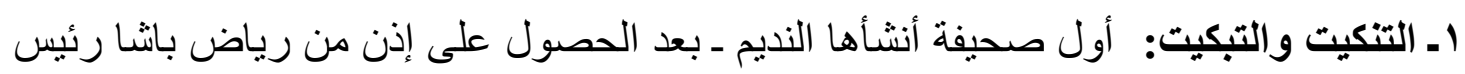

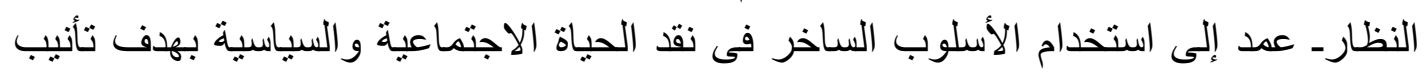

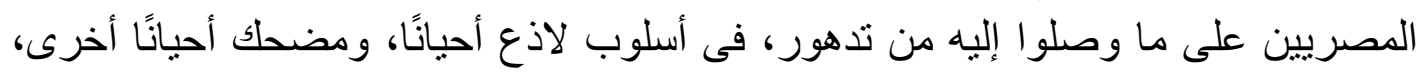

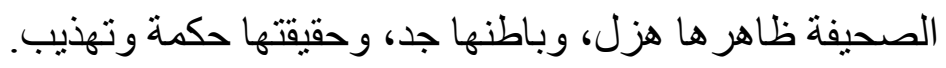


كتب فى تصديره للعدد الأول منها : "هى صحيفة أدبية تهذيبية تتلو عليك حكمًا و آدابًا ومو اعظ وفوائد ومضحكات بعبارة سهلة،

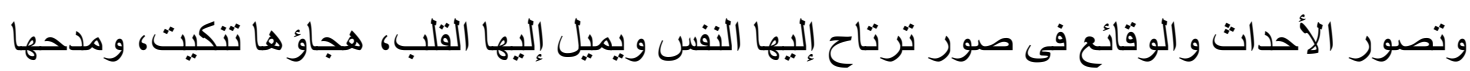
تبكيث، أر ادها صحيفة الخاصة و العامة من أبناء الأمة" (1).

وفى VI أكتوبر |>1 |م أرسل أحمد عرابى إلى النديم أن تكون موضوعات الصحيفة سياسية تهذيبية للدفاع عن حقوق الأمة، و الدفاع عن حكومتها التوفيقية ورد عليه النديم قائلا:

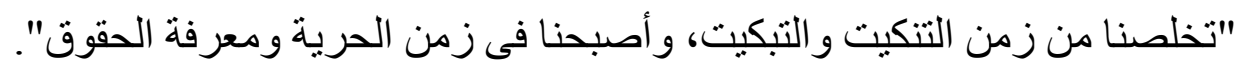
فقد اشتملت هذه الصحيفة على : ا ـ موضوعات ركزت على نق تصرفات الحكام والأجانب وتذكير المصريين بأمجادهم، ودعوتهم إلى التصدى للعادات والتقالبد الو افده من أوروبا إلى مجتمعنا و إظهار مثالبها منها:

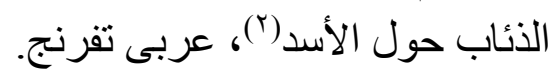

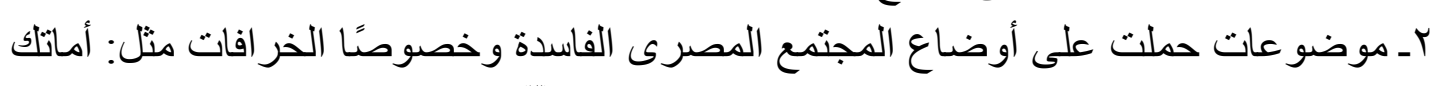

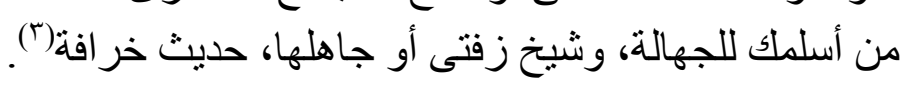

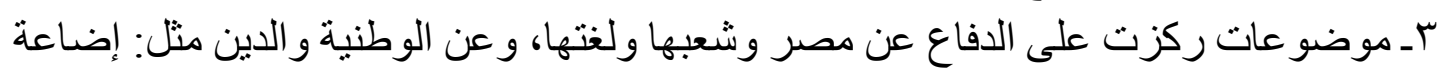

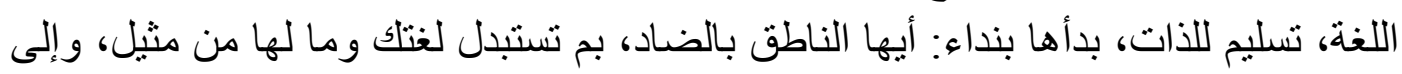

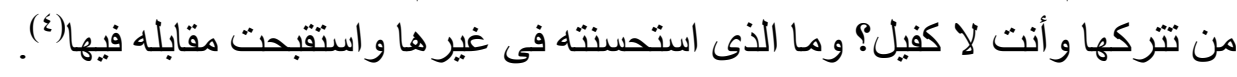
اهتم النديم بمر اسلة القر اءو الإجابة عن أسئلتهم، سؤال بأى سبب ماتت صنائع الثرق و افتقر

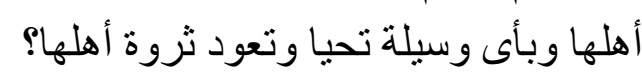

الجو اب: ماتت الصنائع بفساد أهلها وتباغضهم اللذَّين أورثاهم الفقر وفقد الأمن و التقة بهر (ْ). وفى التبكيت حوار بعنوان "وصية نديم لأحد أبنائه"؛ وهو حوار متخيل بين ما يسميه النديم

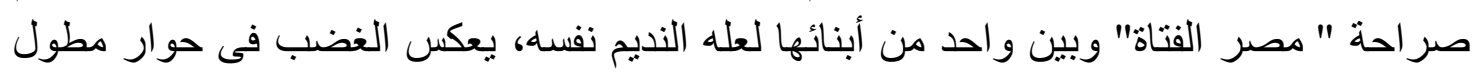

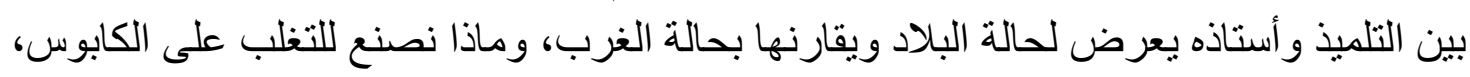

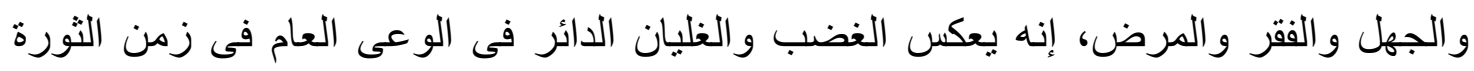
العر ابية(T).

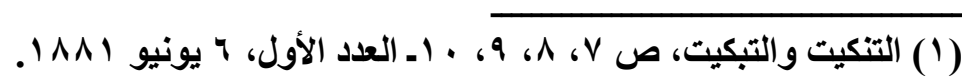

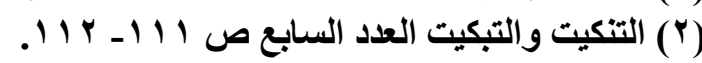

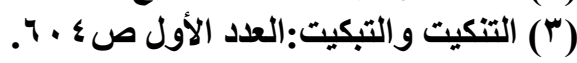

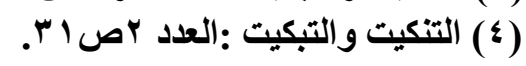

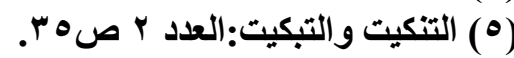

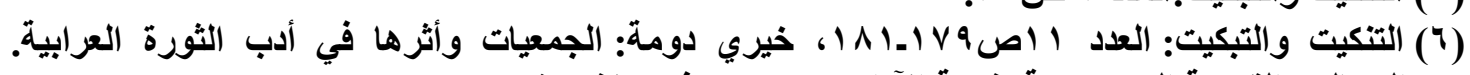

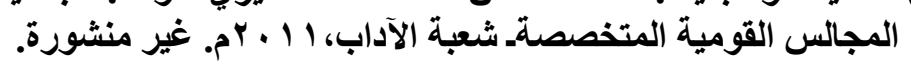


وللسخرية اللاذعة من الحياة السياسية، أغلقت السلطات الجريدة.

r ب الطائف:

أنشأ النديم صحيفة "الطائف" وهى صحيفة سياسية ناصرت الثورة العرابية، ونشر فيها

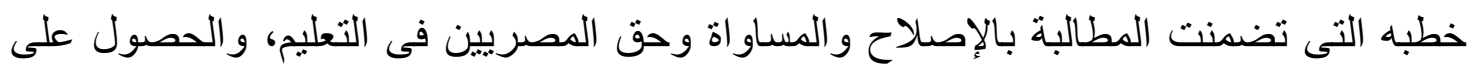
حقو قهم.

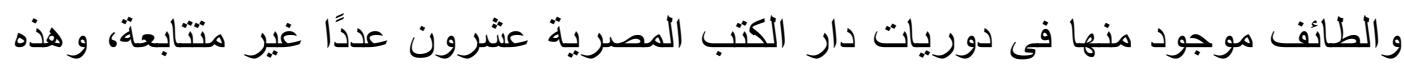
الصحيفة لاقت إقبالا كبيرًا، واحتلت المكانه الأولى بين القراء فى ذللك الوقت، إلا أنه قد مزقها

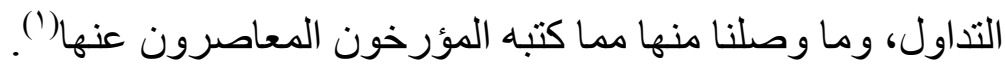
إلا أن دوام الحال من المحال فقد قامت المعركة وضرب الإنجليز الإسكندرية فأغلقت

و هى صحيفة أدبية صدر عددها الأول فى أغسطس 199 ام، قبل صدور الهلال بأسبوع و احد، أنشأها النديم ليتصدى لقوات الاحتلال الإنجليزى ويزيل الغشاوة عن عيون من صدق أن أن إنها الإنجليز لا يتعدى دور هم حماية الخديوى، هذه الصحيفة أثرت فى وجدان ومشاعر المصرينين، و الز عماء منهم: مصطفى كامل، ومحمد فريد و غير هما.

الأستاذ مدرسة الوطنية الصادقة، وكانت أعلى توزيعًا حتى من صحيفة الأهر ام اليومية.

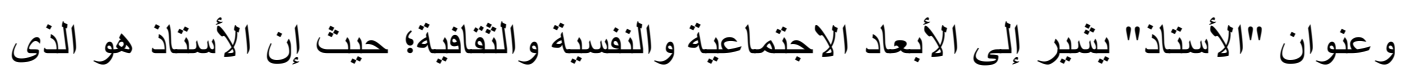
يربى ويعلم؛ ولهذا عرض فى هذه الصحيفة موضوعات مهمة جذبت الكتاب المصريين

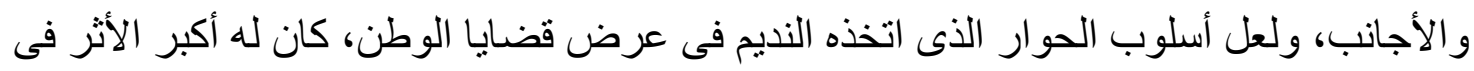
نفوس المصريين، و هذا حوار بعنوان المر افقة الوطنية. التديم والتعليم : n

عرض النديم فكره المتقدم على عصره بأن يكون التعليم لجميع طبقات الثعب بحيث لا

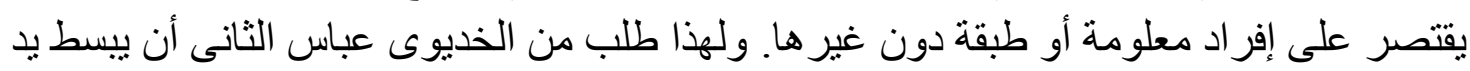

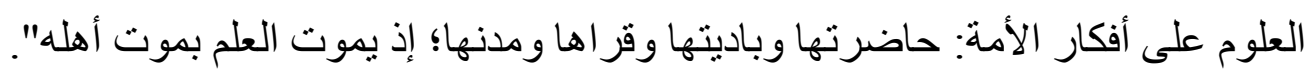
وطالب النديم الأهالى بالإكثار من فتح المدارس الأهلية فى المدن والقرى لتعليم الأبناء، كما

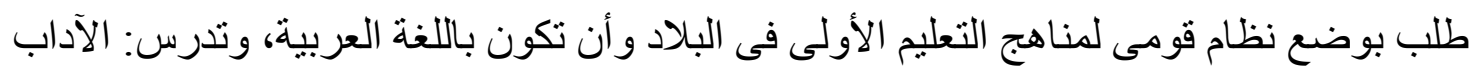

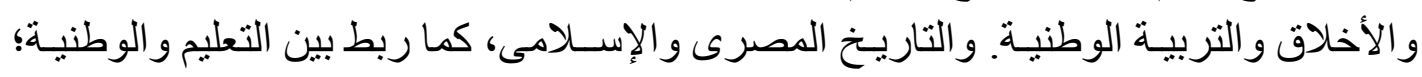


فر أى أن انتشار التعليم من أهم عناصر الوطنية، وحث على غرس دروس الوطنية فى نفوس

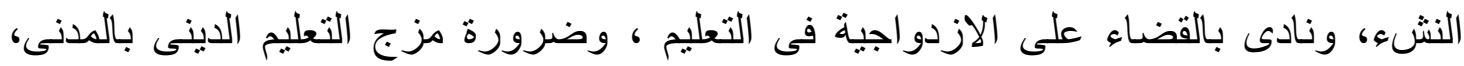
ووضح أن أوروبا وصلت إلى ما هى فيه، عندما فعلت ذللك.

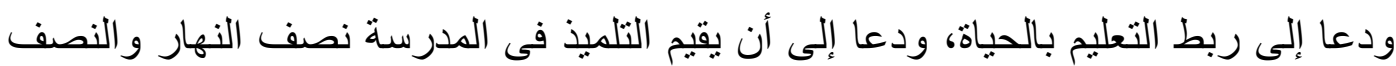
الآخر يشتخل فى صنعة أبيه أو الصنعة التى يختارها: وفى كل سنة تتظر الحكومة فى جداولى رداول الامتحان وتأخذ أصحاب المجاميع الأكبر للتعليم العالى، وتخفف عنهم المصروفات التهات، فتصير البلاد منارة للأدباء، ومأوى للنبهاء من أبناء الوطن.

كما نادى بتثقيف التلاميذ، وطبق ذلك فى مشروع المدرسة الخيرية التى كان بدير ها.

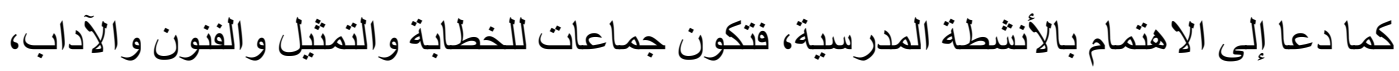
وكتب مسرحية: الوطن، وطالع التوفيق. ورواية "النعمان" وكلها مثلت فى هذه المدرسة وقام التلاميذ بأداء الأدوار، أمام الأمراء

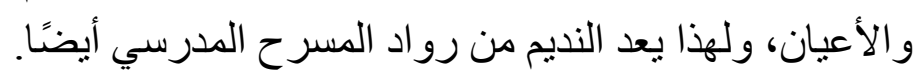
ركز النديم على أهمية الاهتمام باللغة العربية بحيث يكون التعليم فى جميع المر احل باللغة العربية لأن اللغة هى سر الحياة؛ وهى و عاء الفكر، و إضاعة اللغة تسليم للذات كما ذكرنا. و اهتم بتحديد دور المدرس ودور التلميذ ونهى عن معاملة التلاميذ بالثدة بل المعاملة بالرفق

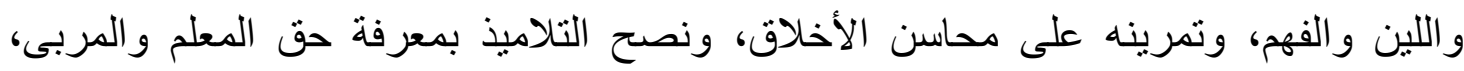

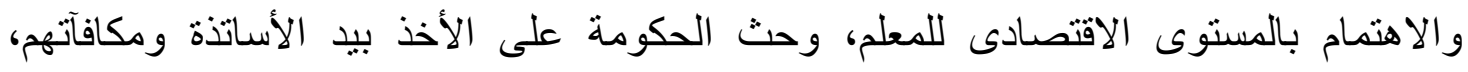

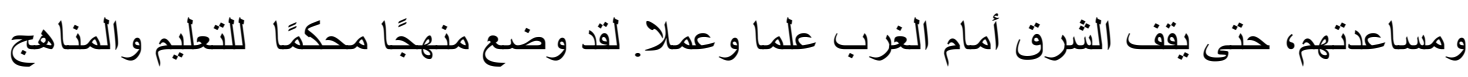

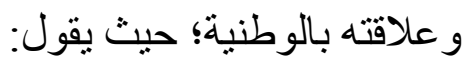

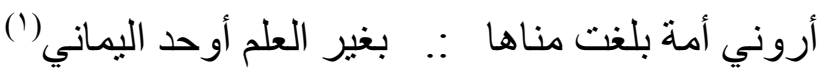

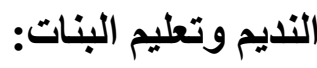

طالب النديم بضرورة الاهنمام بتعليم البنات، وافتتح سلسلة من المقالات فى صحيفة

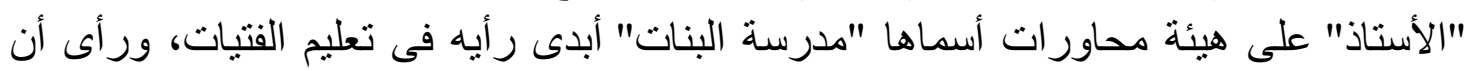

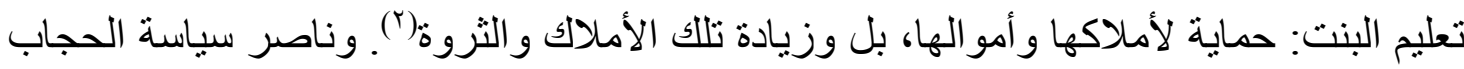

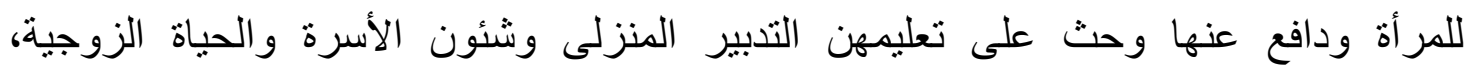

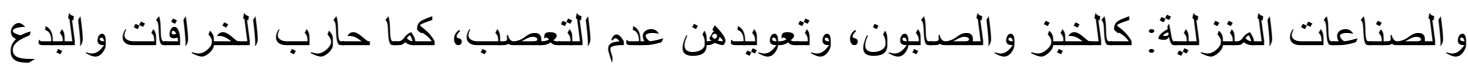

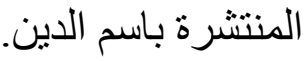


ودعا إلى الاختلاط و التعرف على التقافات المختلفة وتعلم اللغات الأجنبية لأنه منبع من منابع الأبحر العلمية(') والاطلاع على ثقافة الآخر "ومن اطلع على لغة قوم أمن مكرهم". النديم والتعليم الأزهرى:

نظر النديم إلى التعليم الأزهرى ونصح الأزهريين؛ حيث قال: "وددت أن لو كان الأزهريون

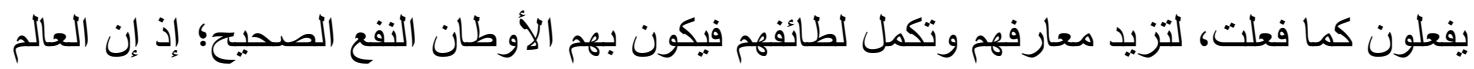

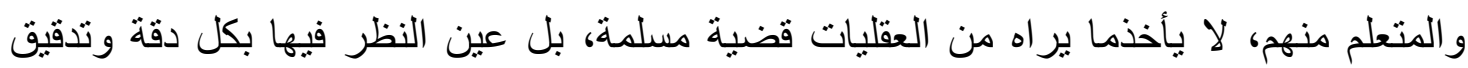
وتأمل حتى يقف على حقيقتها"(r). كما دعا إلى تطوير الأزهر، و احتر ام رجال الدين وتوفير الحياة الكريمة لهح. ودعا إلى تطوير الخطبة، وتطوير المساجد، بحيث تكون المؤسسة الثاملة لتعليم وثقافة المجتمع و الحفاظ على هيئة علماء المسلمين، وخاصة أصحاب العمائم و امتدح فى كثير من خطبه

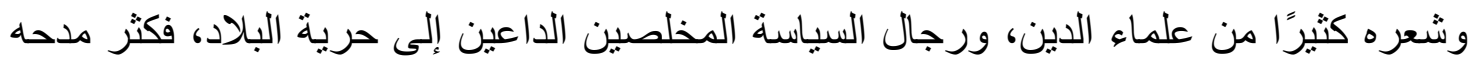

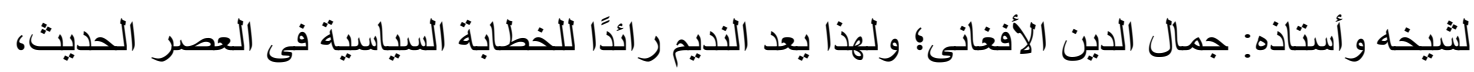

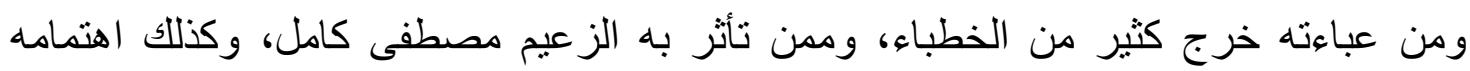
بالخطابة المدرسية بتدريب الطلاب على الخطابة كوسيلة تربوية صالحة لتكوين المو اطن الصالح

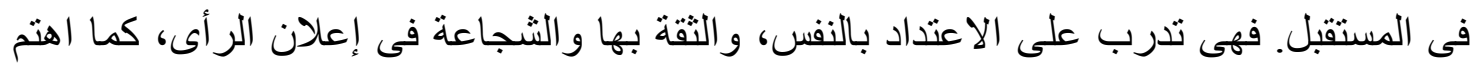
بالخطابة المنبرية للكبار.

\section{النديم والمدارس الأجنبية : م}

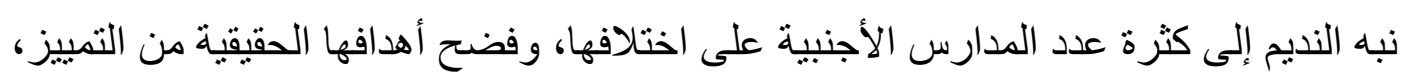

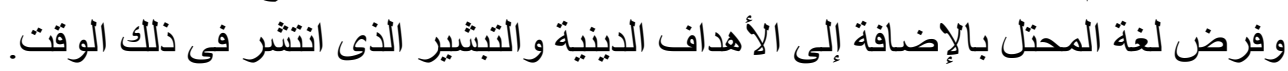
وذكر أن الأهداف الدينية لهذه المدارس تحويل الأقباط المصربين الأرثوذكس إلى المذهب الكاثوليكي أو البروتستانتي، ويوضح أن الهدف هو تبديد وحدة أبناء المجتمع الواحد، أو الدين

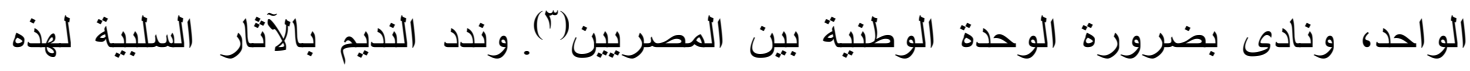

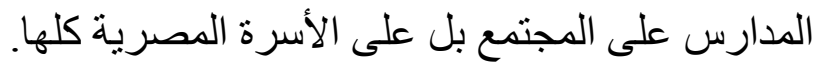




\section{النديم ومجتمع اللغه العربية :}

فى صحيفة الأستاذ دعا النديم العلماء الغيورين على اللغة، فكونوا ما سمى فى ذلك الوقت الته

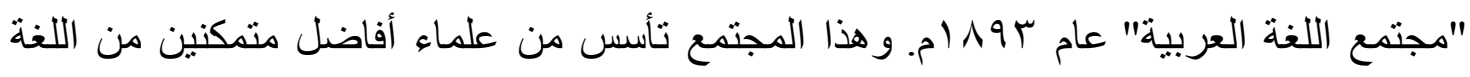

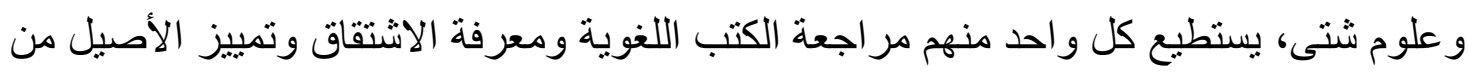

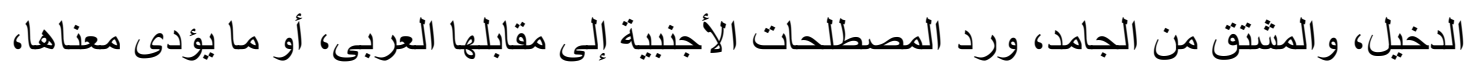

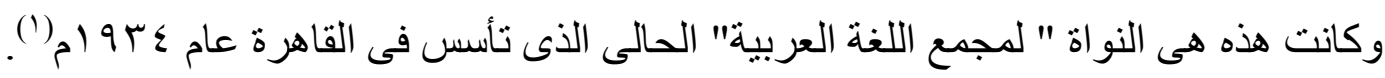
نحو نقد بعض مظاهر المجتمع :

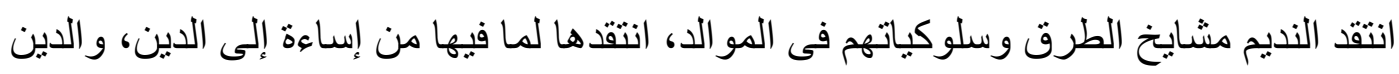

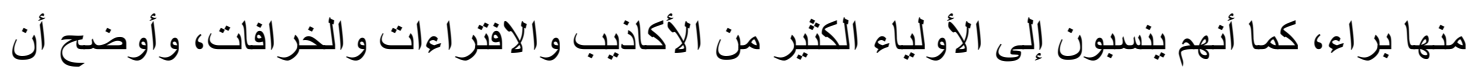

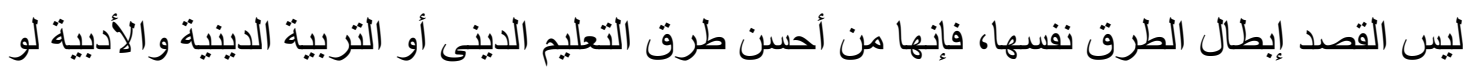

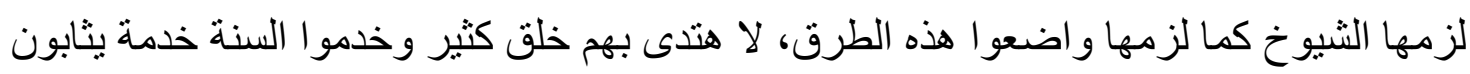
عليها من الله تعالى . كما حارب الثعوذة والمشعوذين فى كثير من مقالاته فى "الأستاذ" وكان النديم يفضح

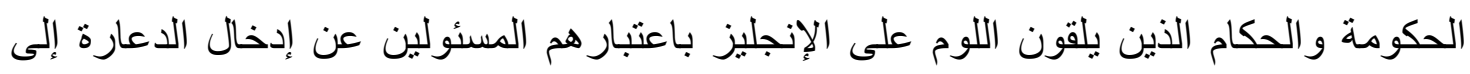
مصر "ونبه على أن الأوربيين الذين هم وراء هذه المفاسد فى المجتمع، وانحلال أخلاق البنات

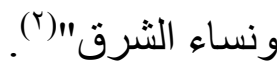

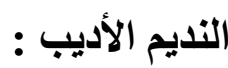

يعتبر النديم نموذجًا عجيبًا فى الأسلوب والإلقاء و التأثنير فى سامعيه. ومن يقر أون له بحيث

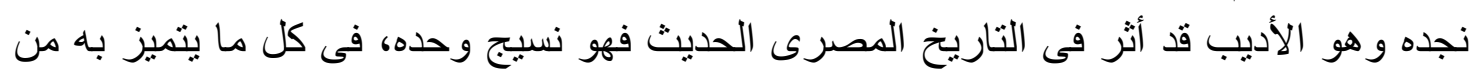

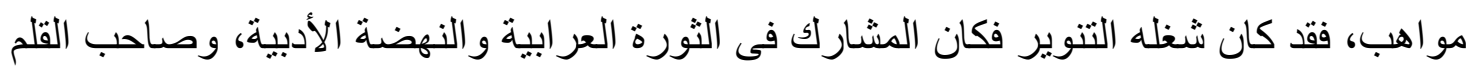
الحر، و الصدق الصادق، و السياسى البارع، والثاعر والزجال، ومؤلف المسرحيات، و المعلم

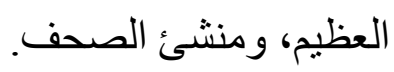

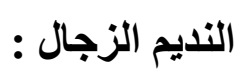

إذا كان الزجل قد نثأ فى الأندلس، فلا شك أنه نما وازدهر فى مصر، و الزجل هو لغة فئ

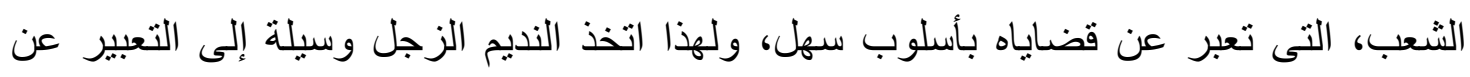

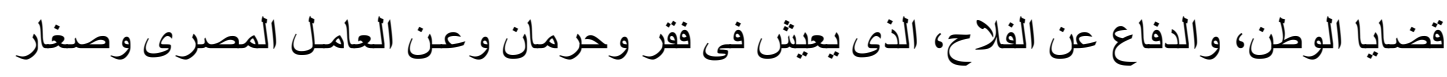

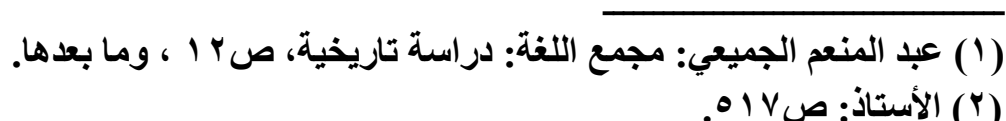


الموظفين و التجار، و أجاد تصوير ابن البلد، وجاب القرى وقدم أزجاله التى تغنت بها الفلاحات

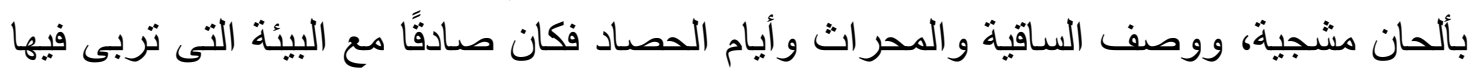

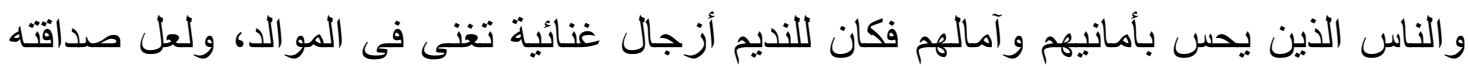

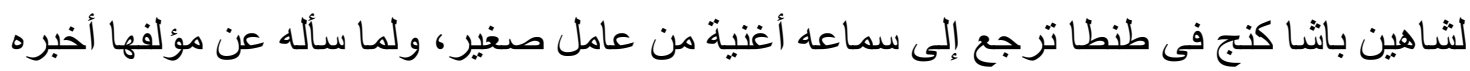

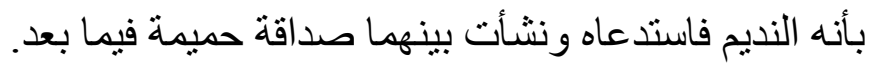
وقد استخدم لازمة فى أزجاله، ذات دلالة بلاغية مجملة "شرم برم" أى شر مبرم استخدمها فى كثير من أزجاله مما كان لها جرس مؤثر فى سامعيه. أولا: كتابات عبد الله التديم : تقترب من نحو (0 r كتابًا وصحيفة، والباقي مفقود) : ا ـ الاحتفاء فى الاختفاء: يعرض لسنوات اختبائه عن السلطة، وكيف احتفى بـه كل من أختبـأ عندهم ، ولم تغر هم المكافأة (ألف جنيه) لمن يعثر عليه أو يرشد عن مكانه، فكان يتخفى في الأي

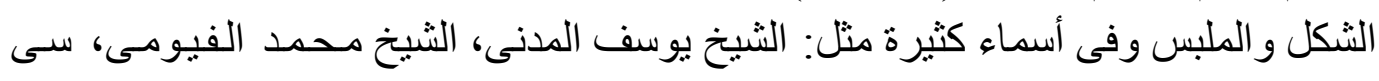

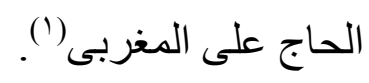
r الأستاذ(؟).

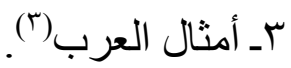

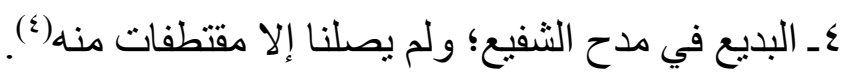

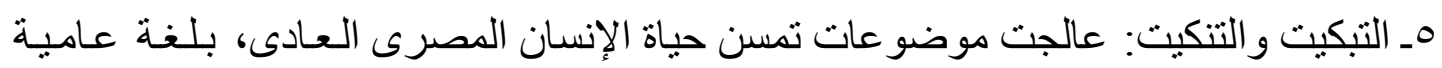

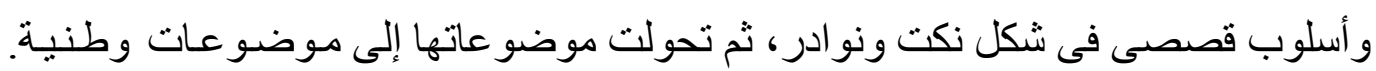

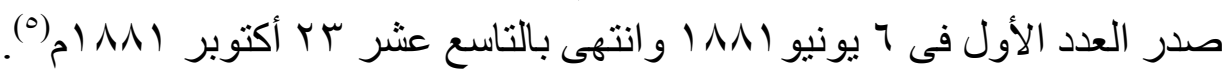

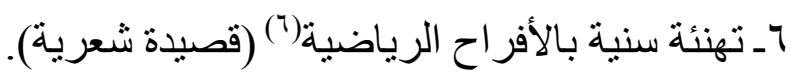

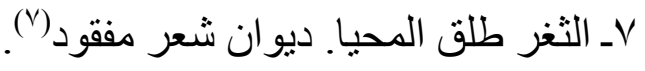

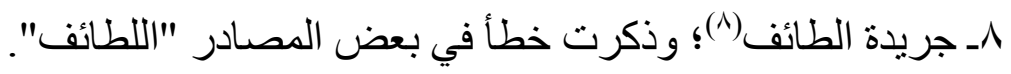

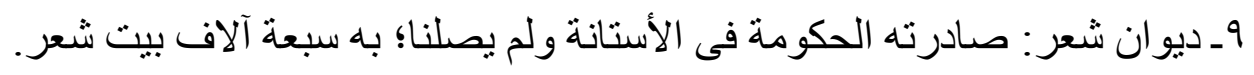

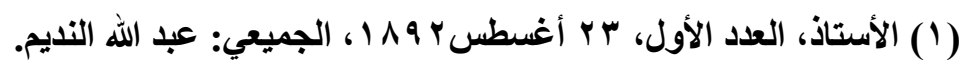

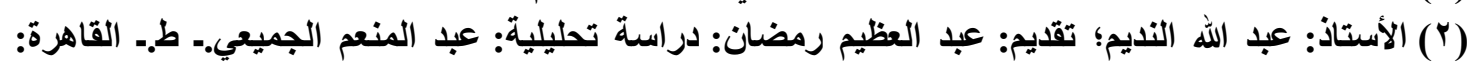

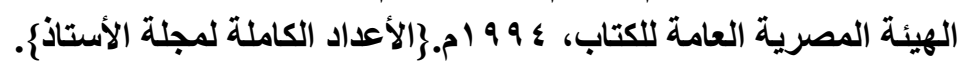

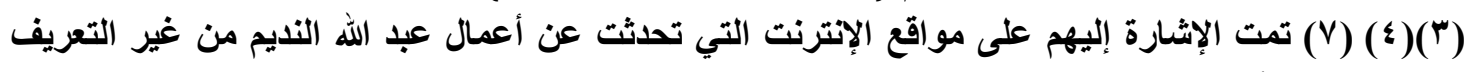
بهم لفقد هم أو لضياع معظمها. . (0) التنكيت والتبكيت: عبدالله النديم.- ط .ـ الإسكندرية: مطبعة جريدتي المحروسة والعصر الجديد؛ عام م $\wedge \wedge 1$

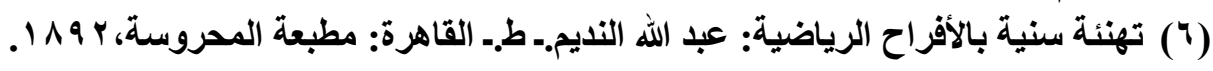

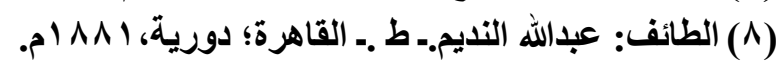


• 1 ـ رسائل أدبية مسجو عة؛ ولم يصلنا منها إلا اليسير؛ ومنها رسالة عنو انها "من عبداله النديم

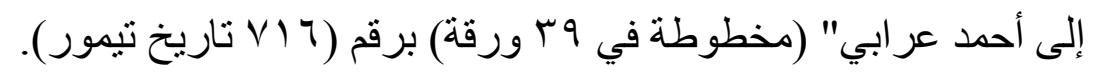

11 إلساق على الساق في مكابدة المشتاق.

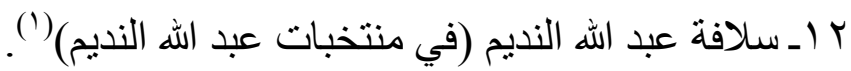

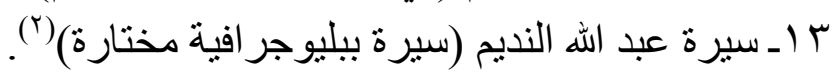

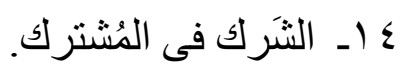

1 1 ـ عبد الله النديم ومذكر اته السياسية(").

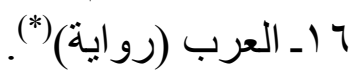
ا ـ ا ـ الفر ائد فى العقائد.

1 ـ كان ويكون: يشتمل على موضو عات أدبية وتاريخية وسياسية ووطنيـة و أصسول ديانـات،

$$
\begin{aligned}
& \text { مطبعة المحروسة } 7 \text { بو } 9 \text { ام (ع). } \\
& 9 \text { ا ـ اللآلى و الدرر في فو اتح التح السور. } \\
& \text { • بـ المتر ادفات. }
\end{aligned}
$$

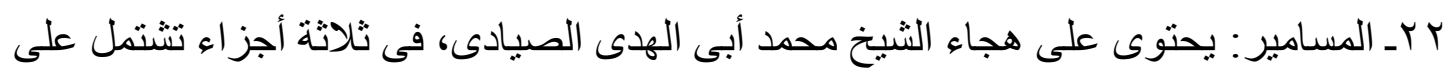

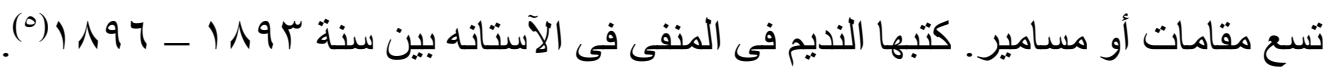

ب ـ المسرحية الاستعر اضية الغنائية.

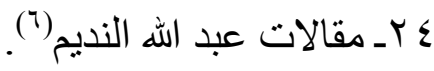

Or ـ النحلة فى الرحلة.

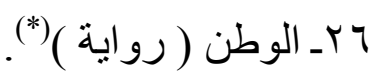

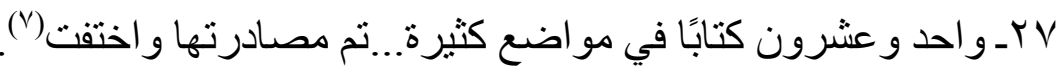

(1) سلافة النديم في منتخبات السيد عبدالله النديم:جمع عبد الفتاح نديم.- ط.- القاهرة: مطبعة الجامعة، م 1 १ V

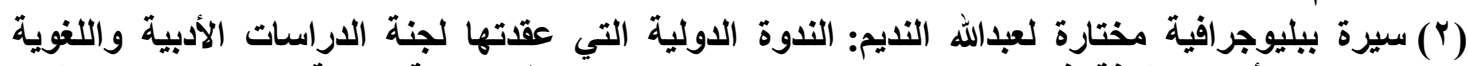

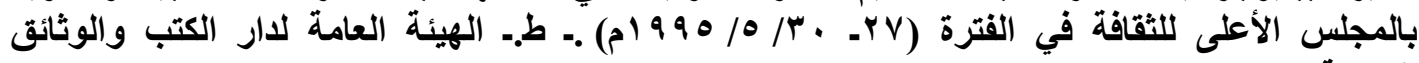

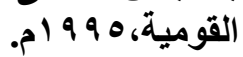
(r) عبدالله ومذكراته السياسية: رسالة عبدالله النديم إلى عرابي: جمع: محمد أحمد خلف.ـ ط.. القاهرة: الأنجلو

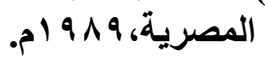

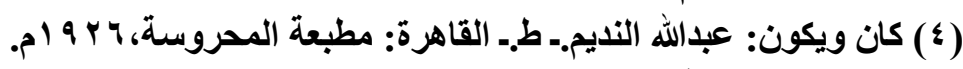

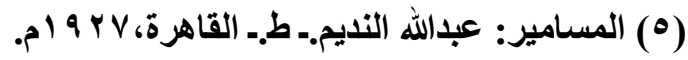

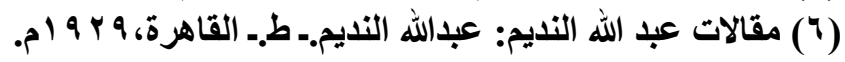

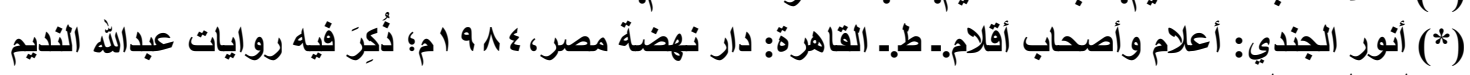

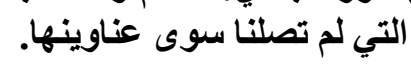
(V) موقع ويكيبديا الموسوعة الحرة على الإنترنت. 
وصفه أحدهم بأنه: "إذا حدَّث سحر ، و إذا أوجز وَدَّ المتحدث إليه أن لو طال". كانت خطبه مصدر قلق وفزع للاستعمار ومعاونيه، وكان أديبا يملك قلمه ولسانه، يتملك قلوب مو اطنيه بأدبه، ويقود الر أى العام بكلهته.

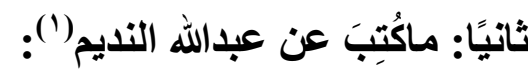
ـ أبو نظارة: إمام الصحافة الفكاهية المصورة وزعيم المسرح في مصر: يتحدث عن رأي أبي نظارة في عبدالله النديم(ب). ـ الصحافة المصرية وأثرها في النهضتين الفكرية والاجتماعية: يستعرض الصحافة المصرية

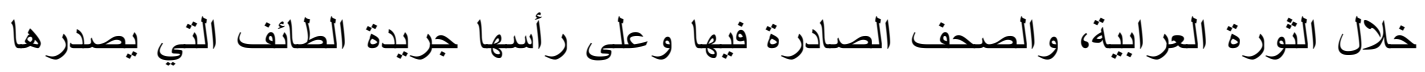
عبداله النديم (").

ـ جريدة الأهرام تاريخ وفن: يتناول فيه إنشاء عبداله النديم جريدة الطائف(؟). ـ عبد الله النديم \}قصص المصلحين والزعماء\{: يشرح بنوع من الإيجاز : حياة النديم، ونشأنه، ودوره في خدمة مصر (ن) - زعماء الإصلاح في العصر الحديث: يستعرض بانور اما لحياة عبداله النديم؛ منذ و لادته وحتى الآن

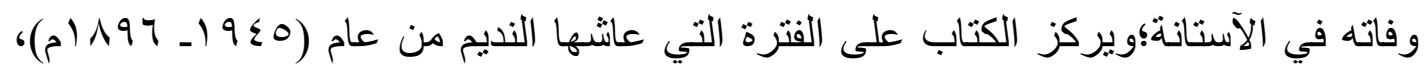

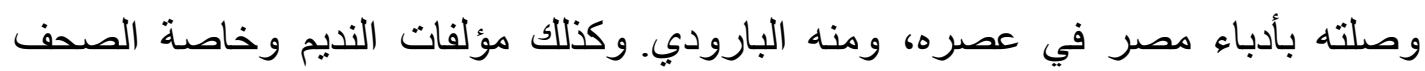

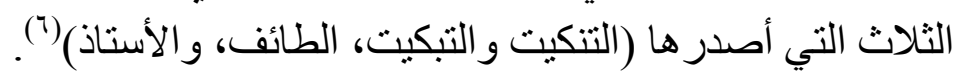
ـ أعلام الفكر الإسلامي في العصر الحديث: يقدم مر احل نشأة النديم، وتعلمه في مجالس الأدب

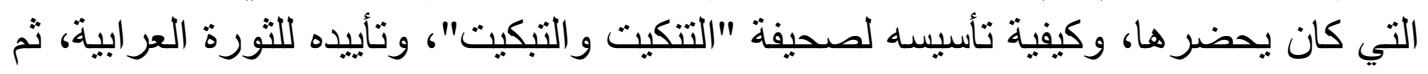

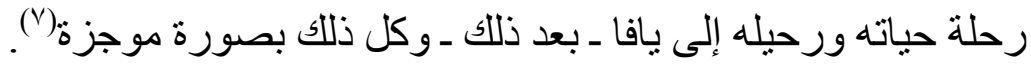

(1) (1) الأعمال مُرنَبة بحسب المؤلف وليس العنوان.

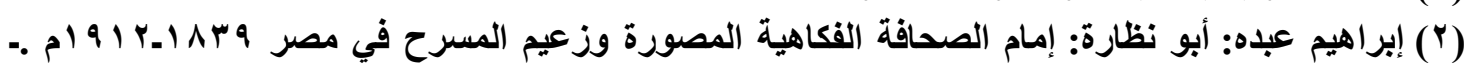

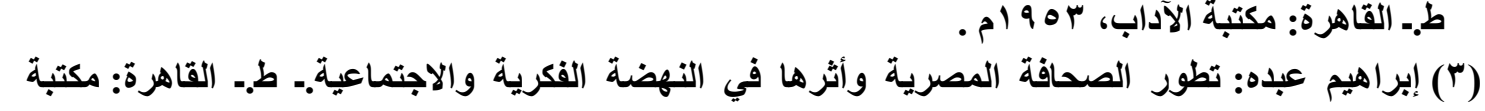

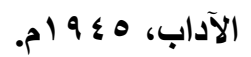

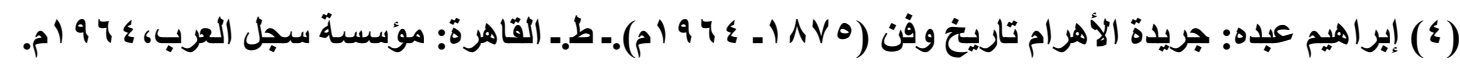

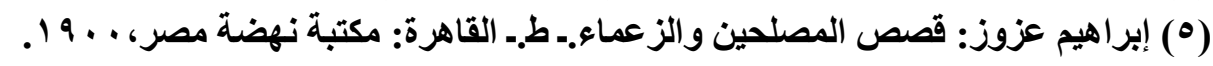

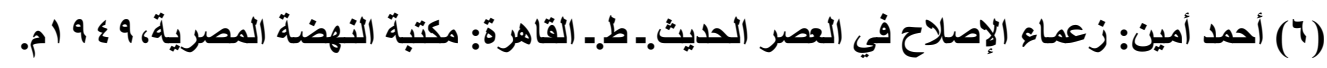

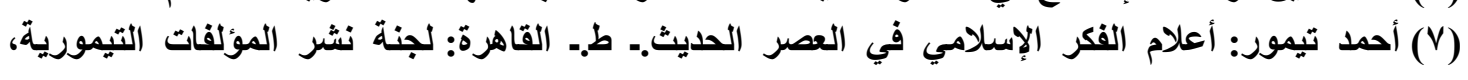


ـ تراجم أعيان القرن الثالث عشر وأوائل القرن الرابع عشر: بشتمل على ترجمة لعبد الله النديم؛ تُعرفِ بهاه، ونسبه، ونشأته، ورحلاته داخل مصر وخارجها، وانتهاء بوفاته بعلة السل،

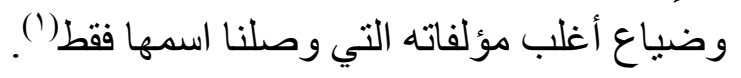

ـ مذكراتي في نصف قرن: يتناول ـ في صفحات قليلة ـ انجار الثورة العرابية، و الفكرية في حينها، وكيف كان عبداله النديم له دور مؤثر، وخطب فئب ثورية(؟).

ـ مصر والمسألة المصرية: ينتقد صحيفة الطائف التي يصدر ها عبداله النديم، وتوجهه إلى في

صحف المعارضة ـ في حينه ـ لمحاولة لم شمل الجماهير في صفوف الثورة العر ابية. (َ). ـ خطباء صنعو التاريخ: يوضح جانبًا جديدًا من جو انب حياة عبداله النديم؛من حيث هجرته إلى إلى

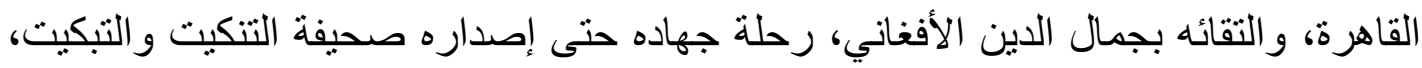

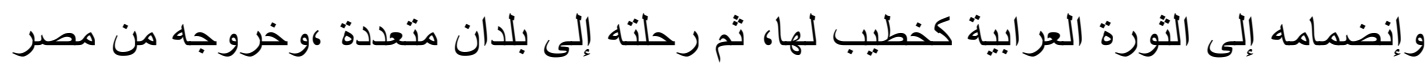

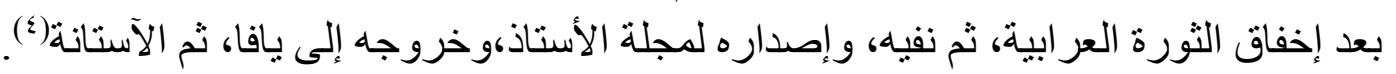

ـ الأعلام الألف: يقدم نبذة مختصرة عن عبداله النديم، وكفاحه أثناء الثورة العر ابية(0.). ـ أعلام وأصحاب أقلام: يتتبع مر احل جهاد عبدالله النديم، و إصداره لصحفه (التنكيت والتبكيت،

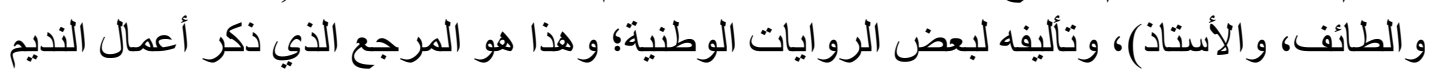

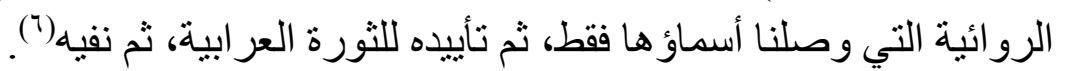
ـ تطور الصحافة العربية في مصر القاهرة: يتحدث عن حال الصحافة في وقت الثورة العرابية

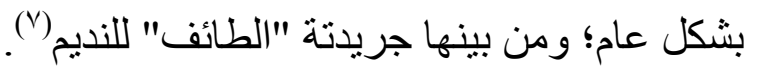
ـ عمالقة ورواد: يتتاول بصورة موجزة جدا حياة النديم، ونشأته، ورحلته في الحياة حتى نفيه(^).

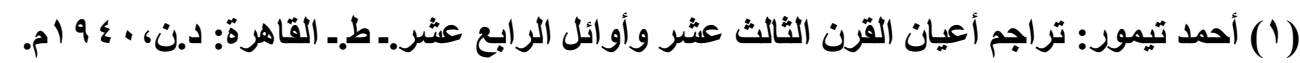

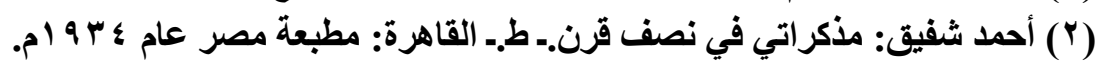

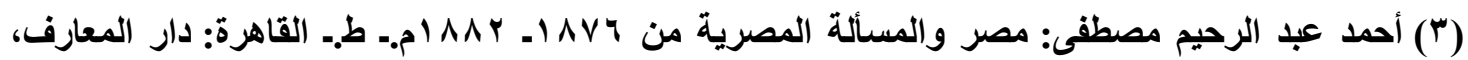
.

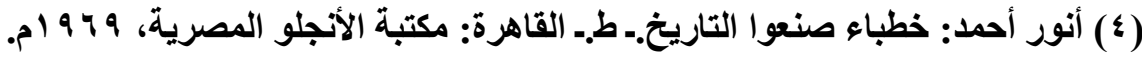

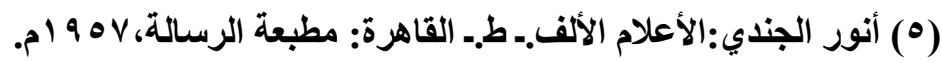

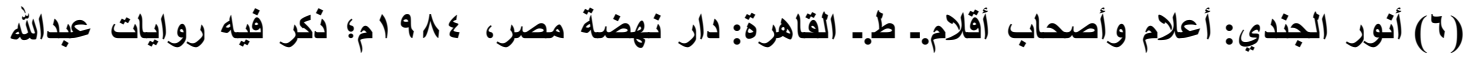

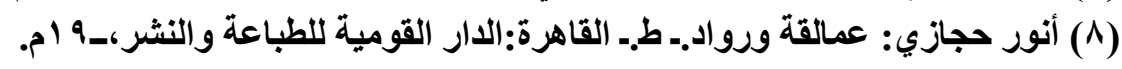


ـ كثف الستار عن سر الأسرار في النهضة المصرية المشهورة بالثورة العرابية: يذكر علاقة النديم القوية بز عماء الثورة العر ابية، وحماسه، وخطبه في الناس لتأييدهال'). ـ مشاهير الثرق في القرن التاسع عشر: فيه تلخيص لترجمة عبداله النديم، واستخلاصها من

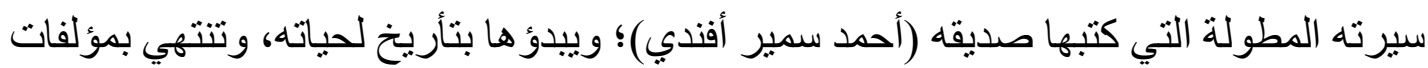

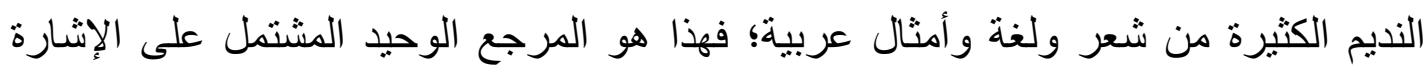

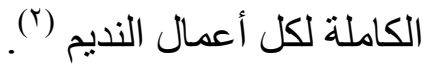

ـ أعلام الإسكندرية في العصر الإسلامي: يُعرفنا بعبداله النديم ونشأته، وتأثره بجمال الدين

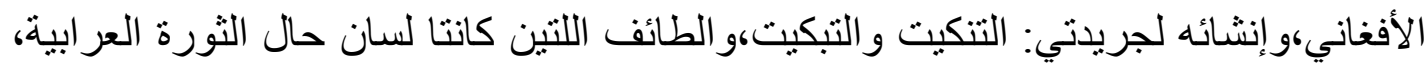
ورحلته بين محافظتي الدقهلية والغربية، ثم إصداره لجريدة الأستاذ، و انتهاء بنفيه إلى الآستانة؛

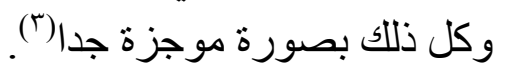

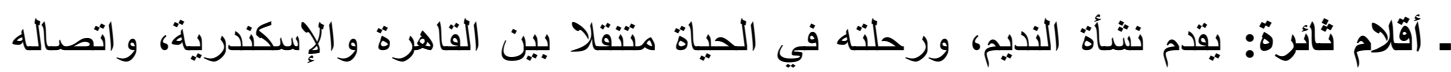

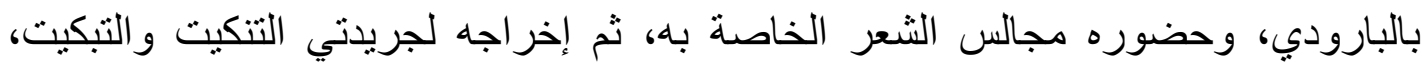

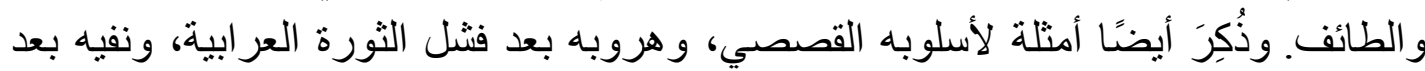

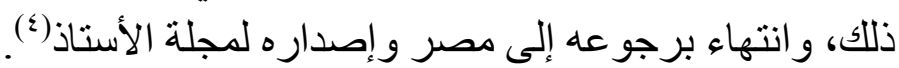

ـ تاريخ آداب الثعب: نشأته، تطور اته، أعلامه: يبدأ بمقدمة عن الشعر، و الموشحات، و الزجل

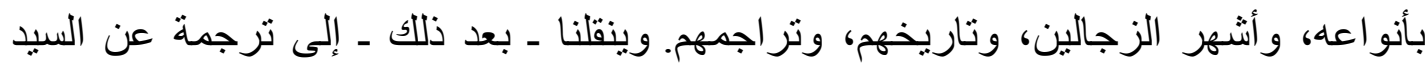

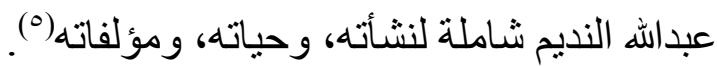

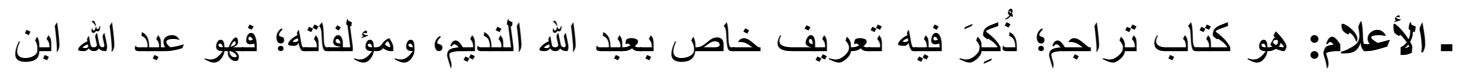

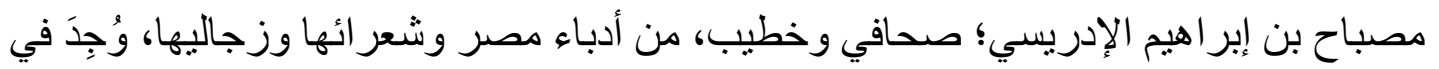

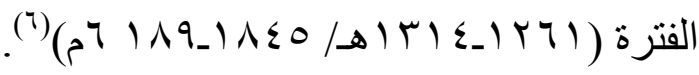

(1) أحمد عرابي الحسيني: كثف الستار عن سر الأسرار في النهضة المصرية المشهورة بالثورة العرابية..

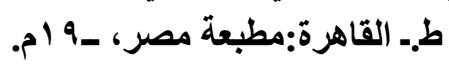

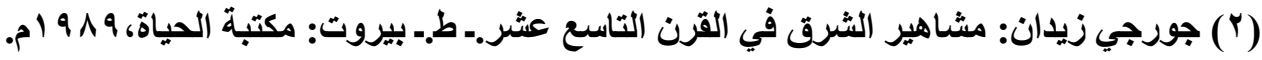

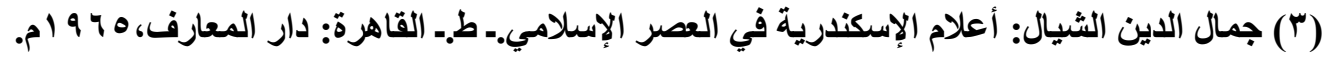

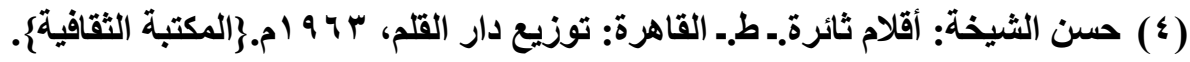

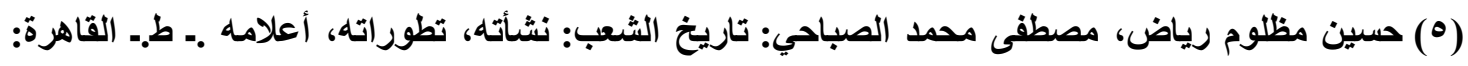

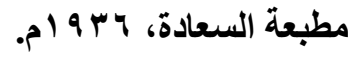

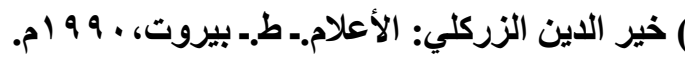


ـ الحرية والعدالة في فكر النديم: كُتببَ عن فكر النديم في خطبه في الثورة العر ابية بيتناول فيه

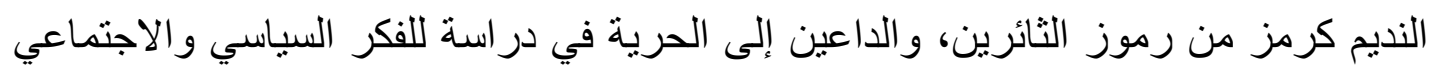

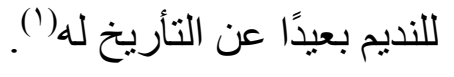

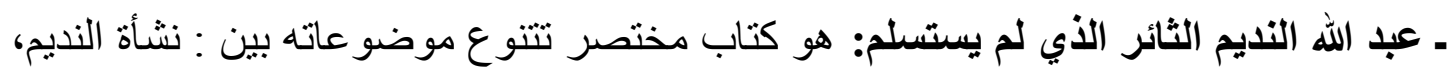

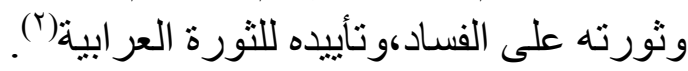

ـ المسرحية الاستعراضية الغنائية "عبدالله النديم"(").

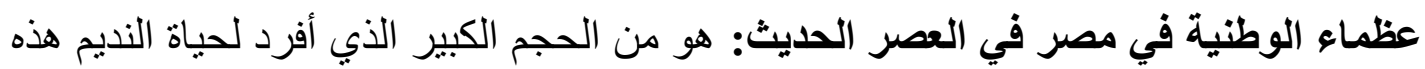

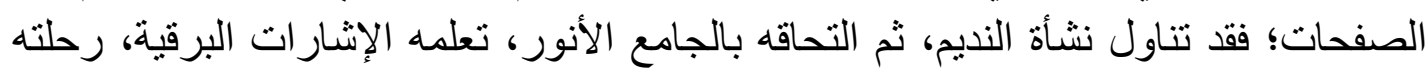

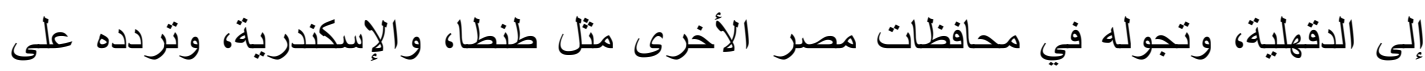

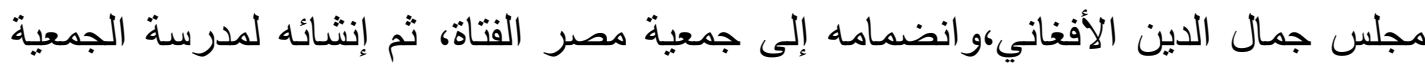

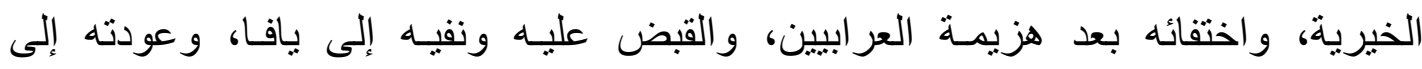

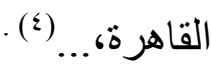

ـ الأدب العربي المعاصر في مصر: يتناول ـ في القسم الخاص بالنثر ـ كتابات عبداله النديم النترية

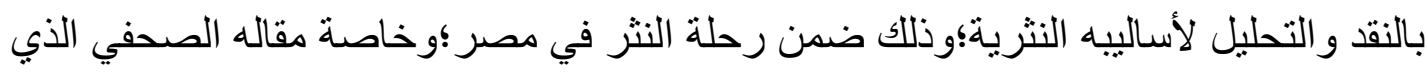

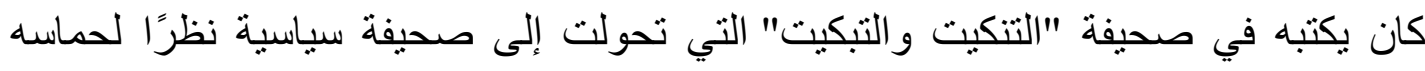

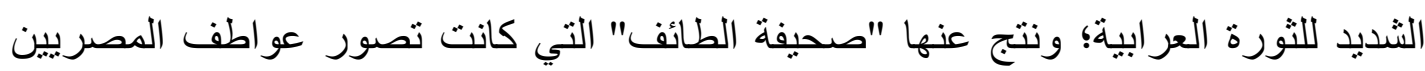
السياسية، وتنادي بالإصلاح في الأداة الحكومية، وكذلك صحيفة الصنية الأستاذ (o).

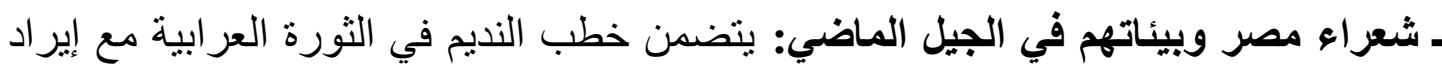

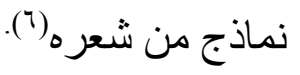

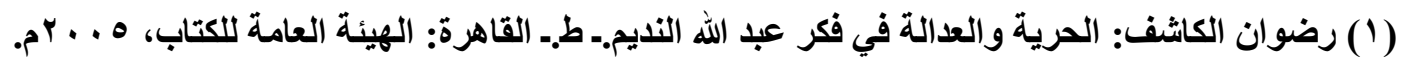

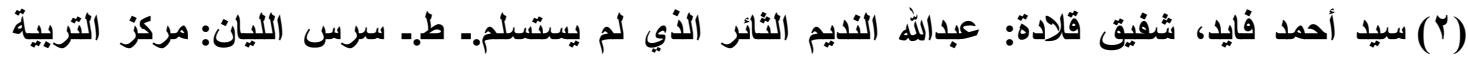

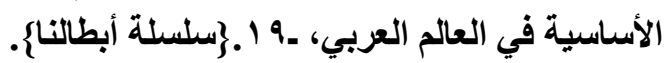

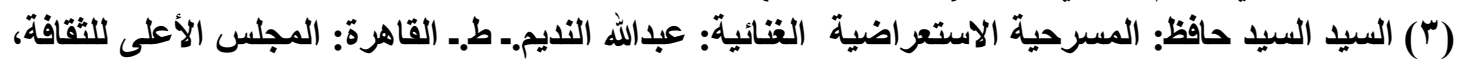
(צ) شحاتة عيسى إبراهيم: عظماء الوطنية في مصر في العصر الحديث.ـ ط.ـ القاهرة: الهيئة المصرية العامة

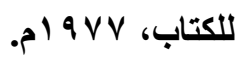

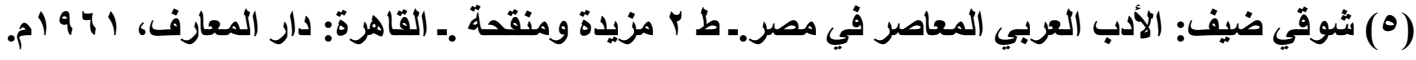

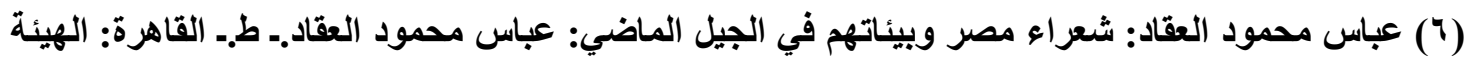

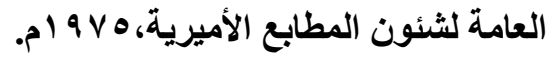




\section{ـ شخصيات لها تاريخ: يثر ح حياة النديم، ومر احل جهاده في الثورة العر ابية(').} ـ الثورة العرابية والاحتلال الإنجليزي: يتضمن شرحًا لحضور النديم في حفلة جمعية المقاصد التيد

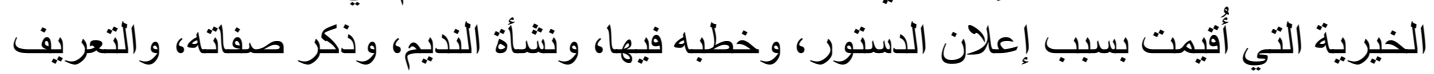

$$
\text { بشخصيته(r) }
$$

ـ الخطابة السياسية في مصر من الاحتلال البريطاني إلى إعلان الحماية: يشرح فكرة النديم

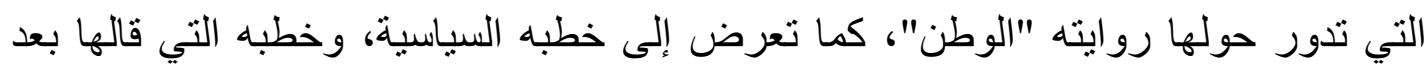
انفر اج الأزمة بين الخديوي و العر ابيين(").

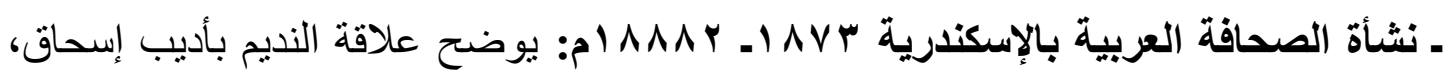

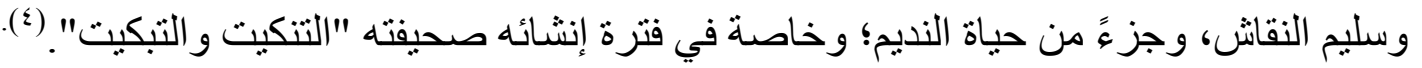

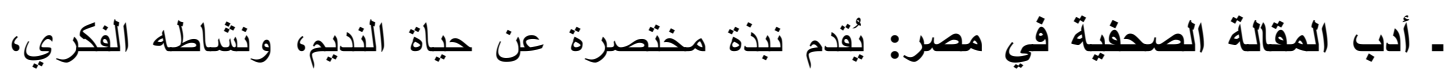
و السياسي (ن). ـ قصة الصحافة في مصر منذ نشأتها إلى منتصف القرن العشرين: في إيجاز شديد يتم الحديث

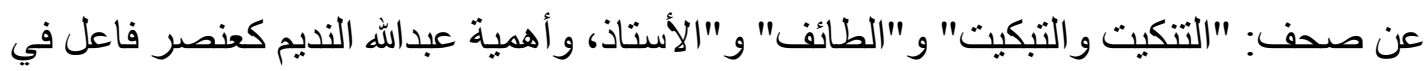
الثورة العر ابية(1) ـ مستقبل الصحافة في مصر: في صورة شاملة موجزة يستعرض حياة الديم، ونشاطه الفكري

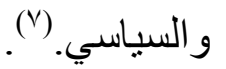

(1) عبد الحميد غرابة: شخصيات لها تاريخ.- ط.- القاهرة: الدار القومية للطباعة والنشر، ب ج أم رمذاهب وشخصيات\{.

(ץ) عبد الرحمن الرافعي: الثورة العرابية والاحتلال الإنجليزي. - طץ. -ـ القاهرة: مكتبة النهضة

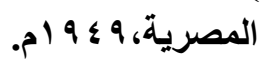

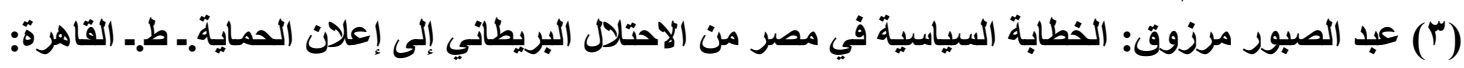

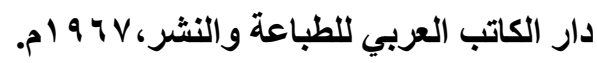

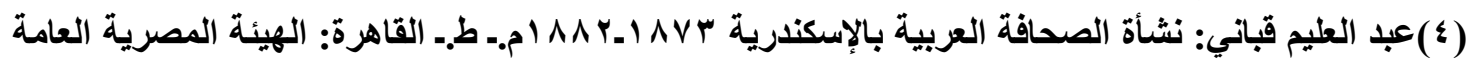

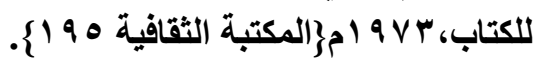

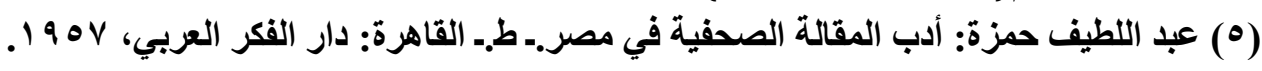

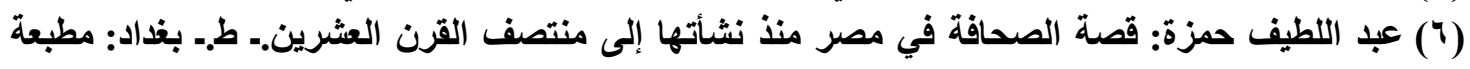
المعارف، V 97 أم.

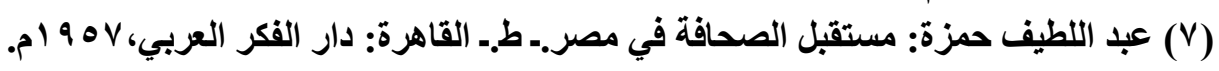


ـ حكاية مصر"حكاية عبدالله النديم": هو بمثابة سيرة وتأريخ لحياة خطيب الثورة العرابية،

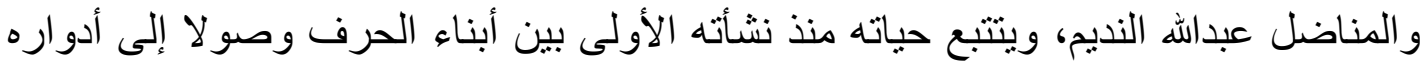

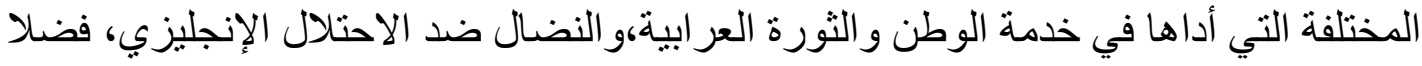

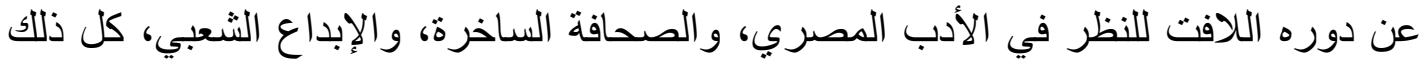

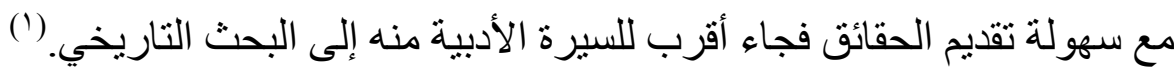
الثورة العرابية: بحوث ودراسات وثائقية: يُيرز دور النديم ومساهمته في الوحدة الوطنية في

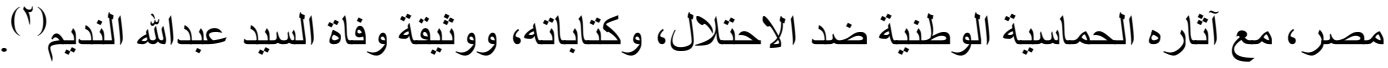
ـ عبدالله التديم ودوره في الحركة السياسية والاجتماعية: في جزء منه مصادر ثقافة التديم،

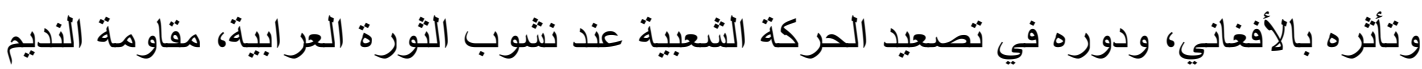

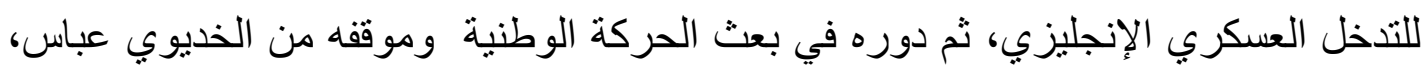

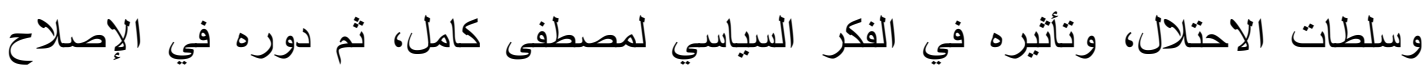

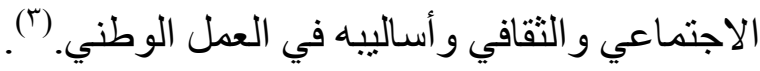
عبدالله انديم خطيب الوطنية: عبداله النديم شخصية تاريخية في التاريخ المصري الحديث؛ فقد

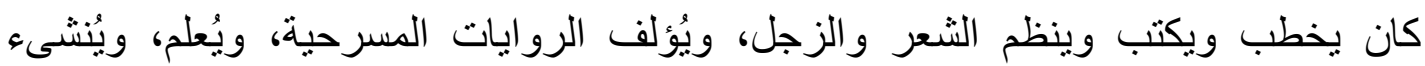

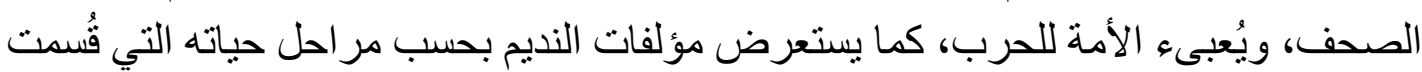

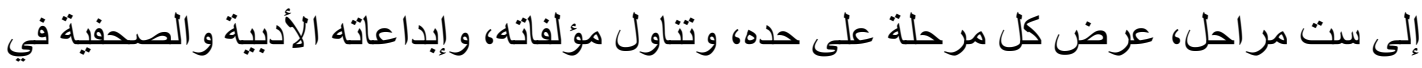

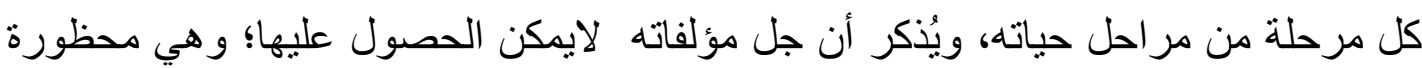

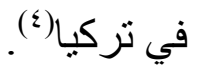
ـ عبدالله النديم وحلم الوطن: يتحدث عن الثاعر الثائر الذي لم يكمل تعليمه؛ وبالر غم من ذلك فقد علم الأجيالـ وترك بصماته في كل شئون مصر ، هو شخصية متميزة فريدة أيقظت و أللهبت شعور المصريين البسطاء(0).

(1) عبد المنعم الجميعي: حكاية عبدالله النديم.- ط.- القاهرة: الهيئة العامة لقصور الثقافة، ب. م.رسلسلة

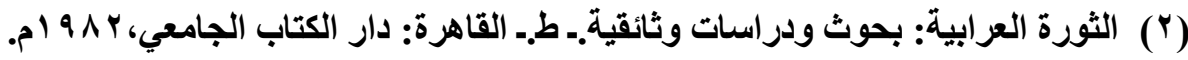

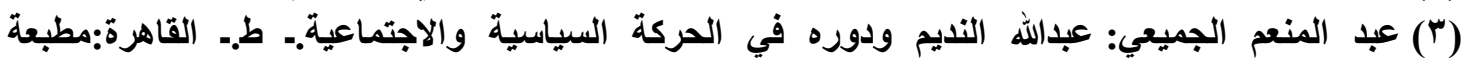
الجبلاوي، • 19 أم.

(؛) علي الحديدي: عبدالله نديم خطيب الوطنية.. ط. القاهرة: المؤسسة المصرية العامة للتأليف والترجمة 
ـ في الأدب الحديث: يتضمن من بين موضو عاته: مر احل حياة النديم في الإسكندرية، ثم في

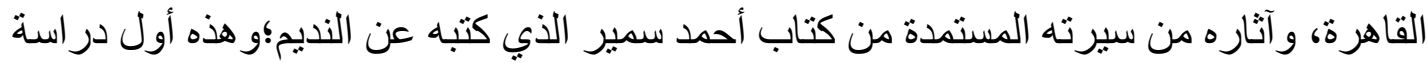

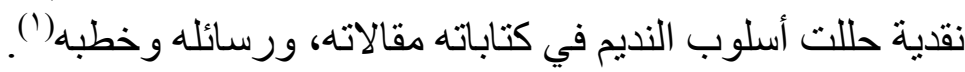

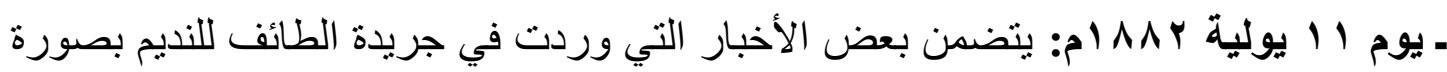
تلغر افية)( آن) ـ مصطفى كامل: ينقل إلينا كيفية اتصال مصطفى كامل بالنديم، وتأثره به شخصيًا، ومن خلال كتاباته(r) ـ صحافة الثورة العرابية في مصر للمصريين: مائة عام على الثورة العرابية: يركز على الدور الصحفي للنديم في الثورة العر ابية في صفحات قليلة(؛). ـ الآداب العربية في القرن التاسع عشر: يوضح طرق إنشاء النديم لصحفه السياسيةهويذكر أمثلة من شعره(1). ـ عبدالله النديم المثقف الوطني الشامل: يُلقي الضوء على حياة وإسهامات عبداله النديم

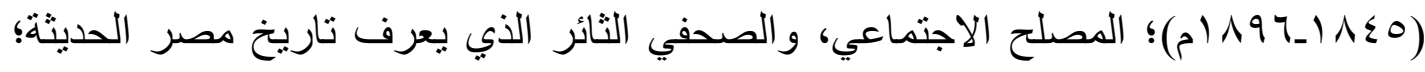

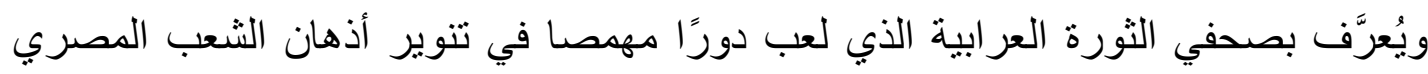

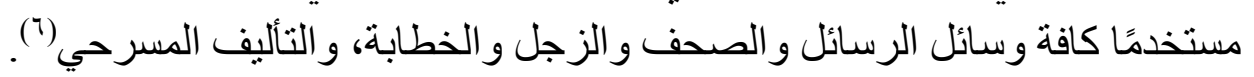
ـ عبدالله النديم ومذكراته السياسية: يتضمن رسالة النديم إلى عرابي يعزيه ويُسري عنه لما

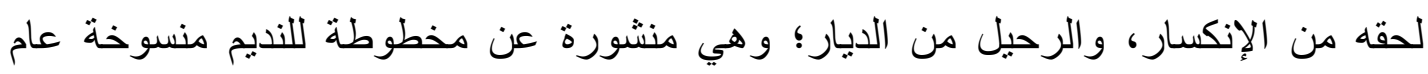

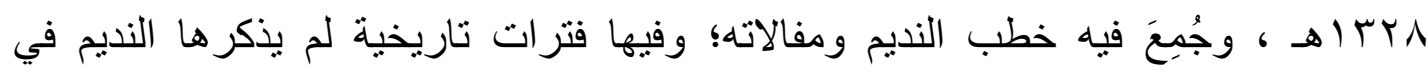

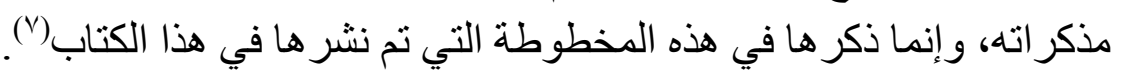

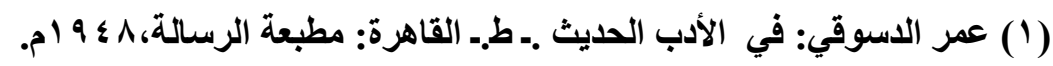

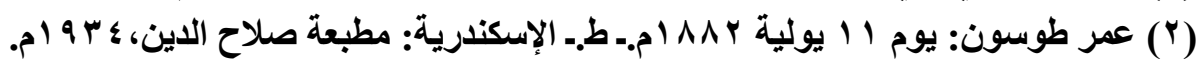

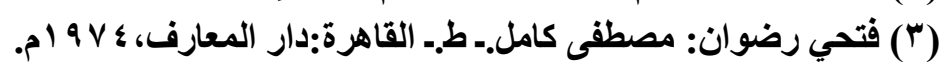

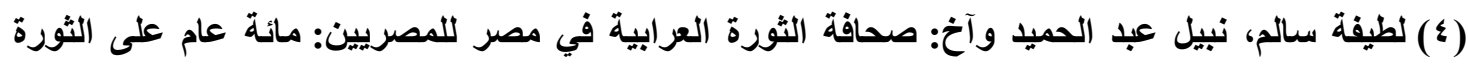

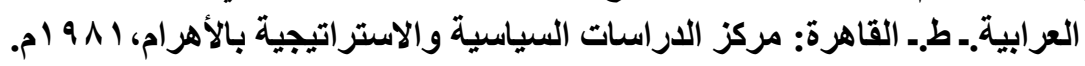

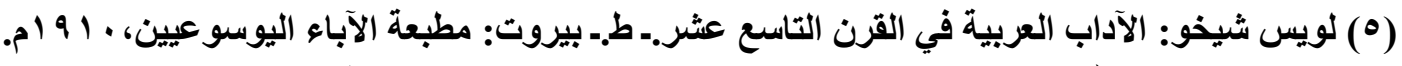

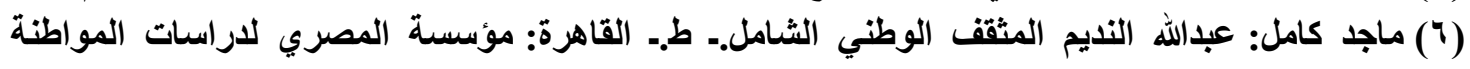

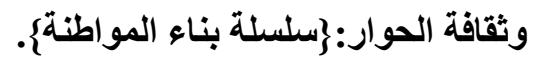
(V) محمد أحمد خلف: عبدالله النديم ومذكراته السياسية.. ط. القاهرة: الأنجلو المصرية، 9 9 أم. 9 م. 


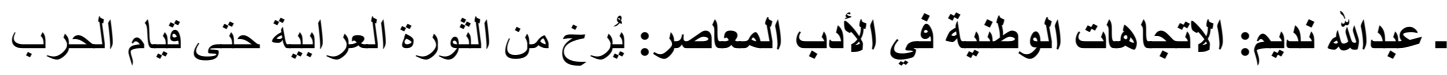

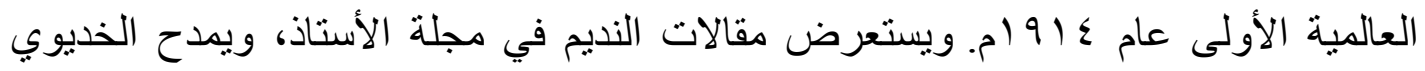

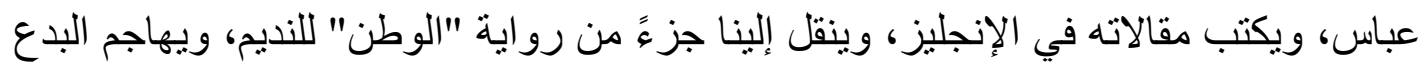

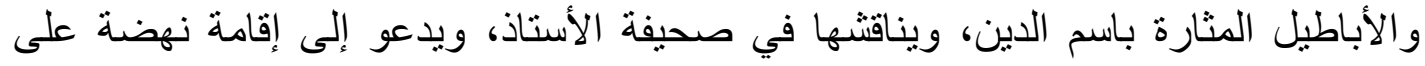

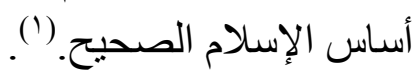

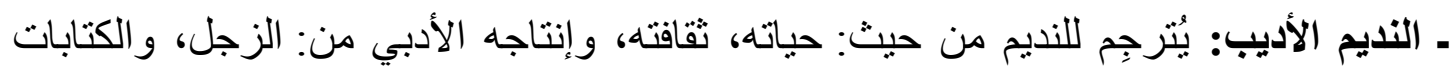

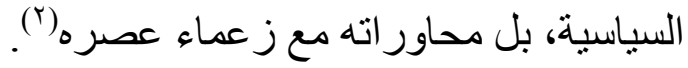
ـ عبدالله النديم: يشتمل على مقدمة تُعرِف بجهاد عبداله النديم مع القورة العرابية، ثم المقالات التي نبهت الثعب المصري بأطماع تركيا العثمانية في مصر، و والنفوذ الأجنبي وحكامه. وكذلك يتتبع مراحل تطور حياة النديم أديب الثورة. وينقسم إلى قسمين: الأول مابعد الثورة، الثيا،

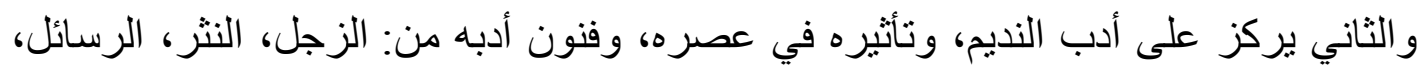
المقالات، و الخطب (َ). ـ الأزهر وأثره في النهضة الأدبية الحديثة: في صفحات متفرقة يتناول صحف النديم الثناث:

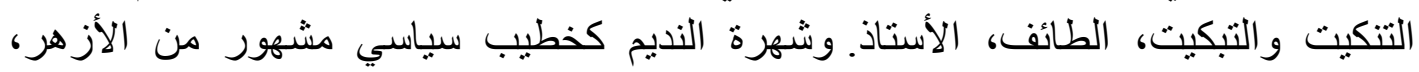

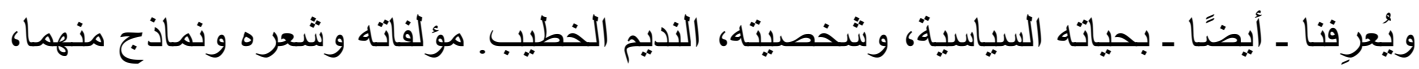
و الآثار الأدبية و العلمية التي تركها مع التركيز على تأثر مصطفى كامل به بـأ.

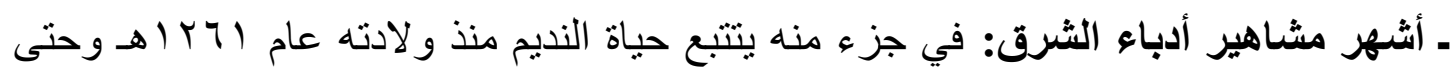

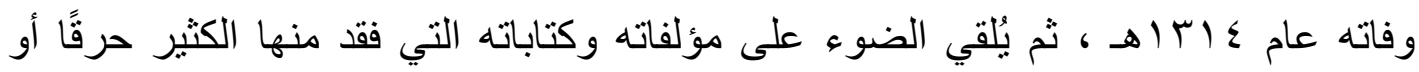
ضياعًا (0) ـ مضامين التربية الثعبية في مجلة الأستاذ لعبدالله التديم: تم فيه تناول مجلة الأستاذ بالشرح و التحليل لمقلاته فيهاب(7).

(1) محمد حسين: عبدالله النديم الاتجاهات الوطنية في الأدب المعاصر.- ط.- القاهرة: مكتبة الآداب عام 1907

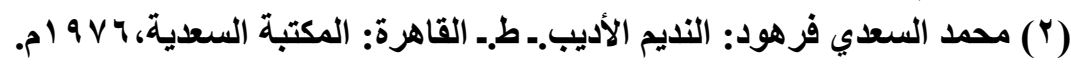

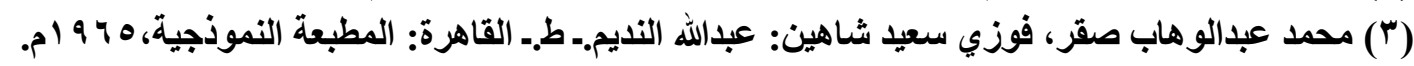

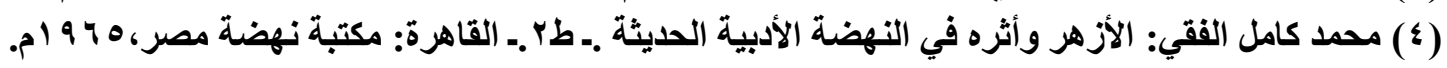

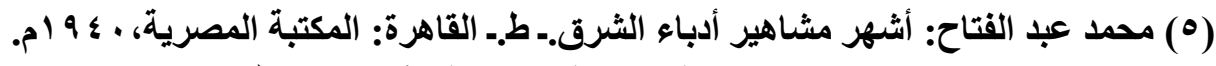

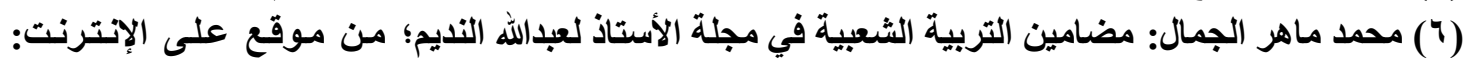


ـ مقالات النديم: أدبية وطنية: يستعرض موضو عات مقالات النديم التى جُمِعت فيه؛ فيصنفها إلى عمر انية، تاريخية، فلسفية('). ـ مصابيح على الطريق: يتناول حياة النديم الحافلة، ومجالس الأدباء التي حضر ها، وانتقاله إلى دالى

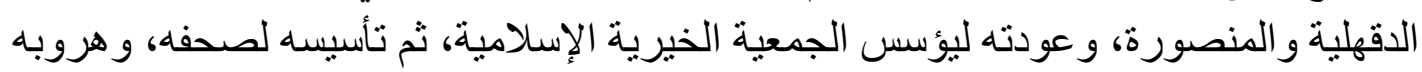

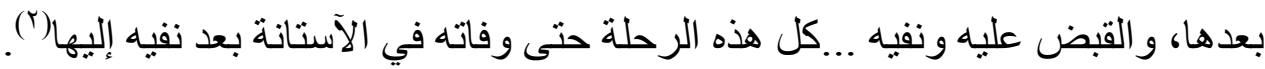
ـ المؤثرات الفكرية في الثورة العرابية: يقدم ـ في صورة مختصرة ـ حياة النديم في بداياته،

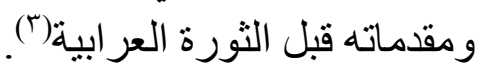
ـ العودة إلى المنفى: يقدم ذكريات بعض المقربين إلى النديم في فترة حياته الأولى التي تنتهي

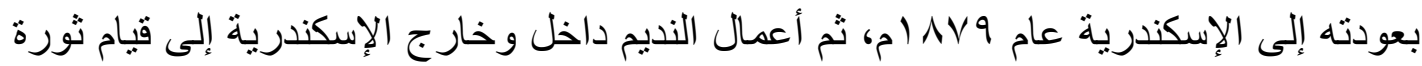

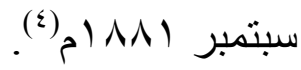

ـ الكافي في تاريخ مصر القديم والحديث: يتناول تاريخ مصر قديمًا وحديثًا؛ وفي هذا الجزء

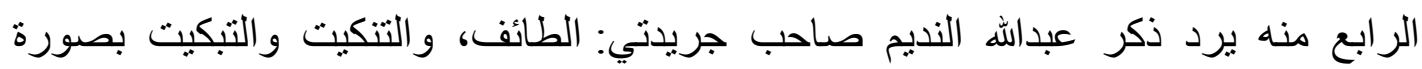

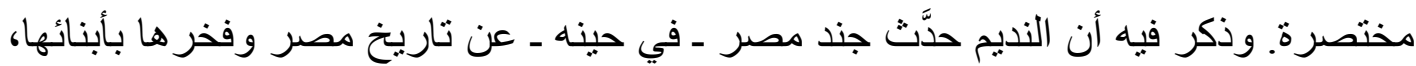

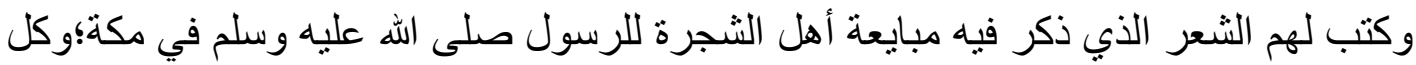
ذللك ليُذَكِر بأيام العرب ليقفو اور اء عر ابي و الثورة العر ابية(0).

ـ من تراث عبدالله النديم: مجلة الأستاذ(ج). ـ الثائر العظيم عبدالله النديم: يتضمن وصفًا دقيقًا لحياة النديم، وصورتيه الجسمانية و النفسية،

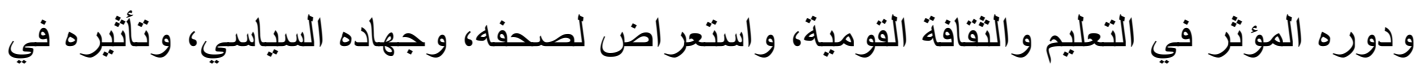

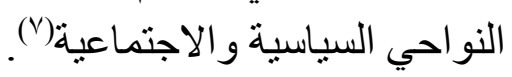

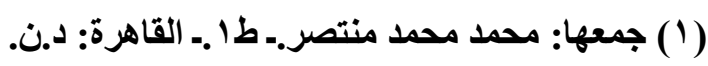

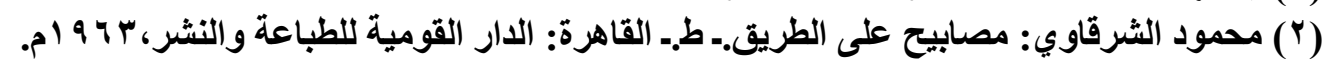

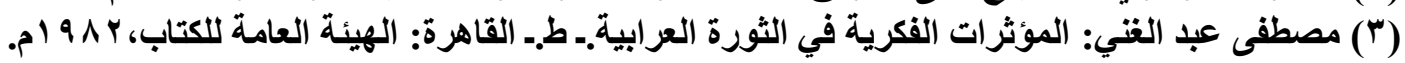

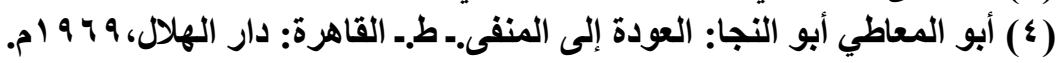

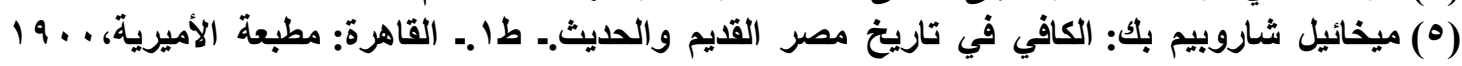

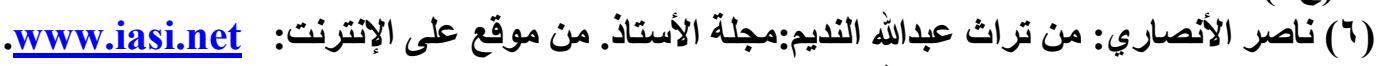

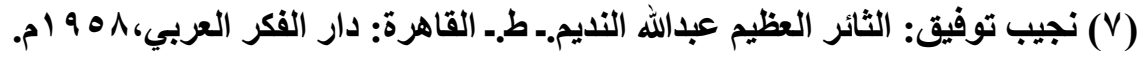


ـ عبدالله نديم خطيب الثورة العرابية: يشتمل على تعريف بحياة النديم من ميلاده مرورًا بنشأته التها

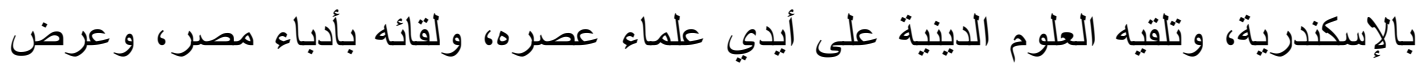
لبعض أعماله الصحيفة والأدبية) (1).

ـ عبدالله نديم بين الفصحى والعامية: يقدم دراسة لشخصية النديم، ويستعرض ثقافته، وشعره

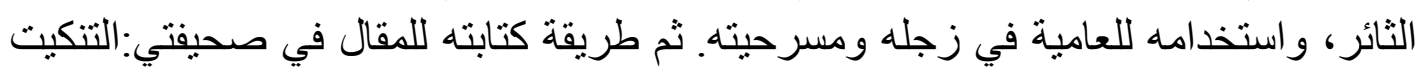
و التبكيت، والأستاذ. و التنوع في استخدام الفصحى و العامية في كتاباته(؟). ـ أعلام من الإسكندرية: في بعض الصفحات حديث عن نشأة النديم، و انتقاله إلى القاهرة، وملازمته لجمال الدين الأفغاني، والتكيز على إنشائه للجمعية الخيرية الإسلامية، وتأييده

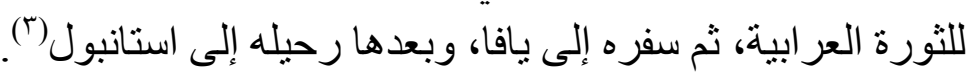
ـ المعلوم والمجهول: في صفحات محددة يتناول جريـدة الأسـتاذ، وموضوعاتها كما كتبها النديم (£).

ـ عبدالله النديم: مسرحية عن تاريخ النديم ورحلته في الحياة(ه). وصفه أحمد تيمور باشا:

"ر أبت رجلا فى ذكاء إياس، وفصاحة سحبان، وقبح الجاحظ، أما شعره فأقل من نثره، ونثره

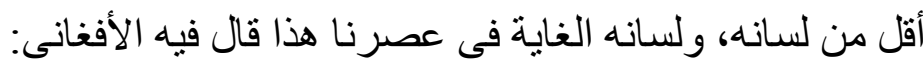
"ما رأيت مثل النديم طوال حياتى فى توقد الذهن، وصفاء القربحة، وشدة المعارضة،

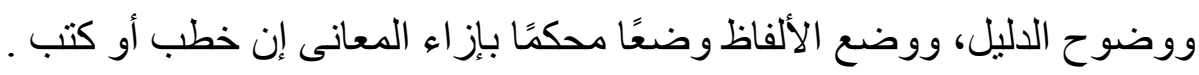
كما بهر النديم الأدباتية فى زجله عندما كان هاربًا من السلطة، وقرأ المقامات العربية،

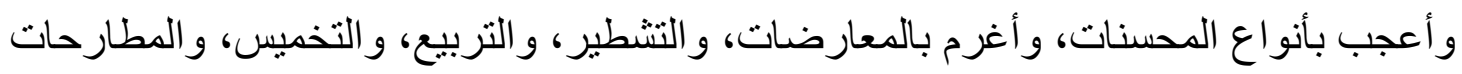

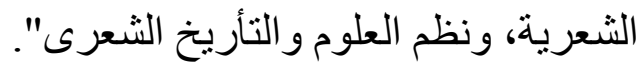

(1) نجيب توفيق: تقديم: عبدالرحمن الرافعي: عبدالله نديم خطيب الثورة العرابية.. ط.. القاهرة: الكليات

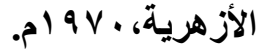

(Y) نفوسة زكريا سعيد: عبدالله النديم بين الفصحى والعامية.. ط.. الإسكندرية: الدار القومية للطباعة

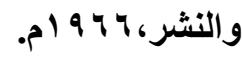

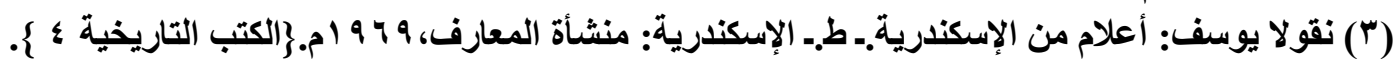

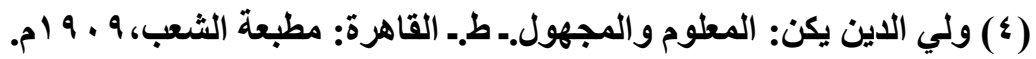

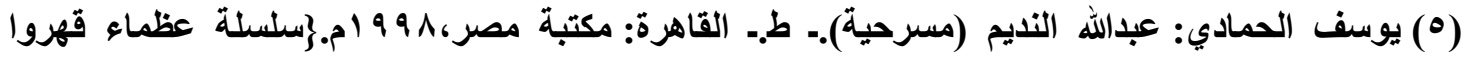
اليأس ج؛ أ). 
و ون كتاباته التى أعجب بها عشاق الأدب، ما كتبه لثيخه العشرى بعد أن أصبح من صفوة

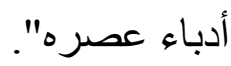
ربيت فأحسنت، وغ وغذيت فأسمنت، مؤدبًا ليثًا ولنت فسوّدت، وجُدت فعودت، مهذبا غيثًا. وكان النديم يكثر من الاقتباس من القرآن الكريم: لا حول ولا قوة إلا باله، اشتبه المراقب باللاه، و استبدل الحلو بالمر ، وقدم الرقيق على الحر، وبيعَ الدر بالخزف، إن في ذلان للك لعبرة.

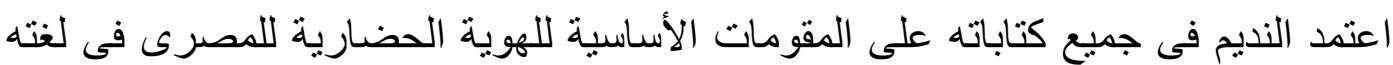

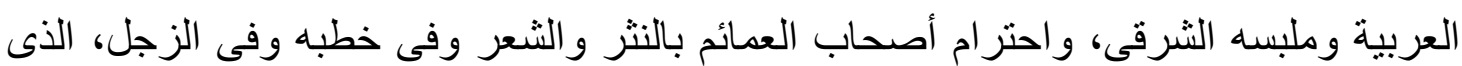
يتميز به النديم . 


\section{الخاتمة}

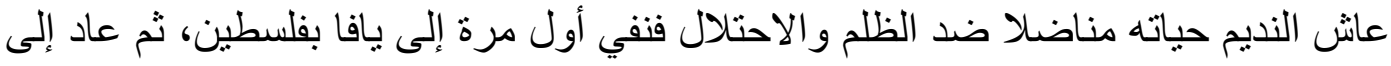

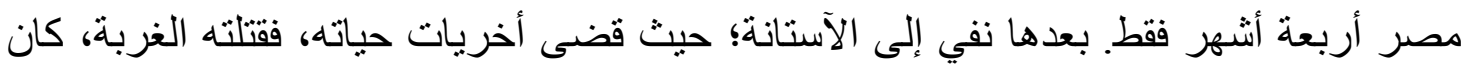

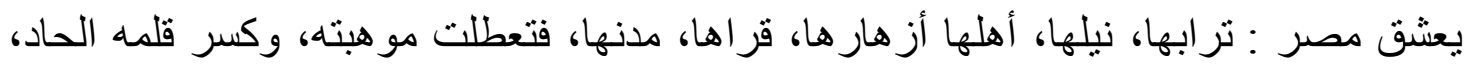

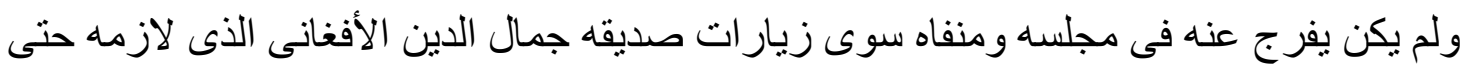

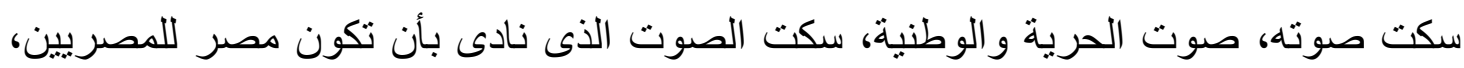

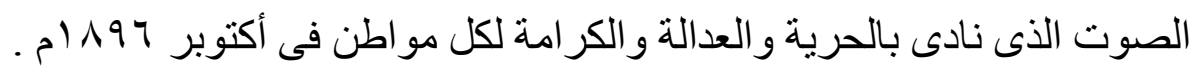

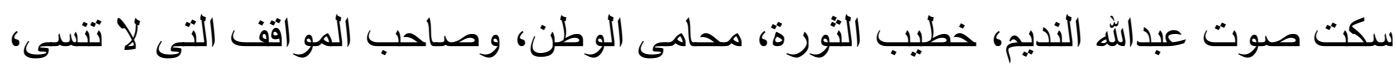

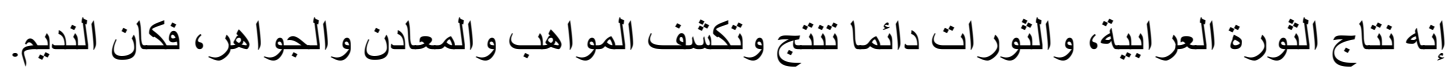
قال الأفغانى عندما وقف على قبره فى الآستانة:

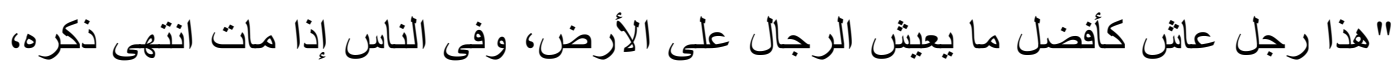

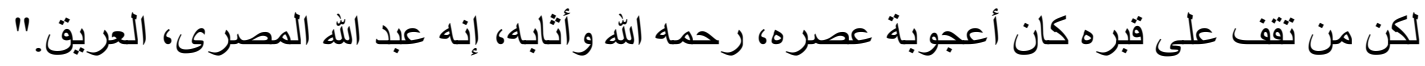

